\title{
Sustaining Collective Self-Governance and Collective Action: A Constitutional Role Morality for Presidents and Members of Congress
}

\author{
Neil S. Siegel*
}

\begin{abstract}
In the United States today, the behavior of the political branches is generally viewed as more damaging to the American constitutional system than is the behavior of the federal courts. Yet constitutional law scholarship continues to focus primarily on judges and judging. This Article suggests that such scholarship should develop for presidents and members of Congress what it has long advocated for judges: a role morality that imposes normative limits on the exercise of official discretion over and above strictly legal limits. The Article first grounds a role morality for federal elected officials in two purposes of the U.S. Constitution whose vindication requires more than compliance with legal rules: securing the American conception of democracy as collective self-governance and creating a reasonably well-functioning federal government. Given its close connection to those purposes, a role morality for presidents and members of Congress is appropriately described as constitutional, not merely political. This Article then proposes some rhetorical, procedural, and substantive components of constitutional role morality, including a commitment to consult the political opposition before taking important actions and a rebuttable presumption in favor of moderation and compromise. The Article also explains how different actors in the American constitutional system should execute their professional responsibilities if they are to make it more, rather than less, likely that such a role morality will eventually be adopted and maintained. A final part anticipates objections, including the concern that the vision offered here faces significant implementation problems.
\end{abstract}

* David W. Ichel Professor of Law and Professor of Political Science, Duke Law School. For helpful suggestions, I thank Jack Balkin, Kate Bartlett, Sara Beale, Joseph Blocher, Jamie Boyle, Curt Bradley, Cinnamon Carlarne, Guy Charles, Ruth Colker, Katherine Mims Crocker, Deborah DeMott, Michael Dorf, Richard Fallon, Edward Foley, Barry Friedman, Claudia Geiringer, Craig Green, Jamal Greene, Mark Hickford, Vicki Jackson, Pam Karlan, Alexander, Kirshner, Maggie Lemos, Marin Levy, Bill Marshall, Toni Massaro, Campbell McLachlan, Darrell Miller, Jeff Powell, David Pozen, Jedediah Purdy, Barak Richman, Stephen Sachs, Chris Schroeder, Peter Shane, Reva Siegel, Marc Spindelman, and Ernie Young. I also thank the participants in an April 2017 conference at Indiana University (Bloomington) Maurer School of Law; a May 2017 faculty seminar at Victoria University of Wellington School of Law in New Zealand; an October 2017 faculty workshop at The Ohio State University, Moritz College of Law; and a November 2017 faculty workshop at Duke Law School. Finally, I thank Jane Bahnson of Duke Law Library for superb help tracking down sources. 
When Rome was in danger, it was the cackling of the sacred geese that saved the Capitol. I am only a professorial goose, consecrated with a cap and gown and fed at a college table; but cackling is my job, and cackle I will. ${ }^{1}$

\section{INTRODUCTION}

Since at least the mid-twentieth century, constitutional law scholarship in the United States has focused on the role of federal judges, not on the role of elected officials. Liberal academics and scholarly judges had defended the constitutionality of the New Deal by arguing that the judiciary should respect the democratically accountable decision-making of the political branches on matters of social and economic regulation. ${ }^{2}$ Those liberals struggled to reconcile their commitment to judicial deference in that sphere with the assertive judicial responses to issues of civil rights and liberties that later arose. ${ }^{3}$

The anxieties of the leading lights of that scholarly generation, most notably Learned Hand $^{4}$ and Felix Frankfurter, ${ }^{5}$ made a lasting impact on their students in the next one. In 1962 , Alexander Bickel famously wrote that the U.S. Supreme Court was a "deviant institution in the American democracy." He coined the phrase "the counter-majoritarian difficulty" to name the perceived problem of democratic legitimacy that arose when unelected judges told popular

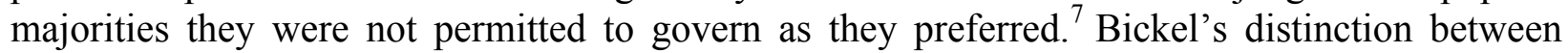
countermajoritarian courts and majoritarian presidents and Congresses would subsequently cast a long intellectual shadow. As Barry Friedman observes, constitutional law scholars since Bickel have been in the grip of an "academic obsession" with the countermajoritarian difficulty. ${ }^{8}$ Much modern scholarship in constitutional law accepts the Bickelian dichotomy between federal judges who are unelected and so (it is assumed to follow) do not represent "majority will," and politicians who stand for election and so (it is assumed to follow) do represent majority will. ${ }^{9}$ All

${ }^{1}$ R.G. CollingwoOd, An EsSAy On Metaphysics 343 (1940). I thank Jeff Powell for this reference.

2 See generally, e.g., Barry Friedman, The Birth of an Academic Obsession: The History of the Countermajoritarian Difficulty, Part Five, 112 YALE L.J. 153, 160-61, 228-36 (2002).

${ }^{3}$ See Brown v. Bd. of Educ., 347 U.S. 483 (1954); Friedman, supra note 2, at 202-15 (discussing Warren Court school prayer, reapportionment, and criminal procedure decisions).

${ }^{4}$ See generally LeARned Hand, The Bill of Rights: The Oliver Wendell Holmes Lectures (1958).

${ }^{5}$ See, e.g., W. Va. State Bd. of Educ. v. Barnette, 319 U.S. 624, 648 (1943) (Frankfurter, J., dissenting) (rejecting the so-called double standard of judicial review in stating that "[o]ur power does not vary according to the particular provision of the Bill of Rights which is invoked").

6 Alexander M. Bickel, The Least Dangerous Branch: The Supreme Court at the Bar of POLITICS 16 (1962).

${ }^{7}$ Id. at 18 .

${ }^{8}$ See Friedman, supra note 2, at 157 (discussing "the intellectual problem of justifying judicial review that has gripped the academy nonstop since the early 1940s”). See also, e.g., Philip BobBitT, ConstituTiOnAL FATE: THEORY OF THE CONSTITUTION 3 (1982) ("The central issue in the constitutional debate of the past twenty-five years has been the legitimacy of judicial review of constitutional questions by the United States Supreme Court.").

${ }^{9}$ See Barry Friedman, Dialogue and Judicial Review, 91 MicH. L. REV. 577, 630 (1993) (observing that " $[\mathrm{t}]$ he countermajoritarian difficulty posits that the 'political' branches are 'legitimate' because they further majority 
such scholarship assumes that, in the American constitutional system, it is the proper role of federal judges, not elected officials, that requires a normative account.

The same assumption animates constitutional law scholarship that imagines it has moved on from Bickel. Such scholarship accepts all of the political science evidence establishing that the Supreme Court is far more majoritarian, ${ }^{10}$ and the political branches are far less majoritarian, ${ }^{11}$ than Bickel and his intellectual heirs imagined. Among constitutional law scholars, however, that learning has been thought relevant mostly to theorizing about judicial review, ${ }^{12}$ putting aside Sanford Levinson's calls for constitutional redesign. ${ }^{13}$ The focus tends to remain on judges, both the formal rules courts make for other actors, and the less formal norms that govern judges themselves. ${ }^{14}$ The most consistent theme in the literature is law in judicial hands, implemented through judicial procedures, with consequent attention to judicial role. ${ }^{15}$

will, while courts are illegitimate because they impede it"). John Hart Ely wrote that "we may grant until we're blue in the face that legislatures aren't wholly democratic, but that isn't going to make courts more democratic than legislatures.” John HART Ely, DemOCRACY AND Distrust: A THEORY OF JUdiCIAL REVIEW 67 (1980). He deemed "ludicrous" efforts to justify judicial review based on the idea that "the legislature does not truly speak for the people's values, but the Court does." Id. at 68. "There can be no doubt," he repeated, "that the judicial branch, at least at the federal level, is significantly less democratic than the legislative and executive." Id. at 206 n.9. Larry Kramer also deemed it "ludicrous" to think legislatures and courts are "comparable" in how much they "mirror or translate popular will.” Larry Kramer, Popular Constitutionalism, Circa 2004, 92 CALIF. L. REV. 959, 999 (2004).

${ }^{10}$ Most political scientists reject Bickel's premise that judicial review presents a countermajoritarian difficulty. For a discussion, see Howard Gillman, Mark A. Graber, \& Keith E. Whittington, American Constitutionalism: Structures of Government 20-21 (2d ed. 2016). Prominent works include Thomas R. Marshall, Public Opinion and the Rehnquist Court (2008); Keith E. Whittington, Political Foundations of Judicial Supremacy: The Presidency, the Supreme Court, and Constitutional Leadership In U.S. History (2007); Thomas R. MARShall, Public OPINION AND the Supreme Court (1989); Martin Shapiro, Freedom of SPeEch: The Supreme Court AND Judicial Review (1966); Kevin T. McGuire \& James A. Stimson, The Least Dangerous Branch Revisited: New Evidence on Supreme Court Responsiveness to Public Preferences, 66 J. PoL. 1018 (2004); and Robert A. Dahl, Decision-Making in a Democracy: The Supreme as a National Policy-Maker, 6 J. PUB. L. 279 (1957). Important legal scholarship similarly contests the premise of a countermajoritarian Court. See generally, e.g., BARry Friedman, The Will of the PeOPle: How Public Opinion Has Influenced the Supreme Court AND SHAPEd the MEANing OF THE Constitution (2009); Jack M. Balkin \& Sanford Levinson, Understanding the Constitutional Revolution, 87 VA. L. REV. 1045 (2001). For skepticism that the Court is "majoritarian," see generally Richard Pildes, Is the Supreme Court a "Majoritarian" Institution?, 2010 Sup. CT. Rev. 103, 117 (2010); Neil S. Siegel, A Coase Theorem for Constitutional Theory, 2010 Mich. ST. L. Rev. 583 (2010) (analyzing Friedman's The Will of the People).

${ }^{11}$ For discussions of political branch countermajoritarianism, see generally SANFORD LEVINSON, OUR Undemocratic Constitution: Where the Constitution goes Wrong (and How We the People Can Correct It) (2006); Paul Brest et al., Processes of Constitutional Decisionmaking: Cases and MATERIAls 147-51 (6th ed. 2015); Corinna Barrett Lain, Upside-Down Judicial Review, 101 GeORGETOwn L.J. $113,144-157$ (2012).

${ }^{12}$ See generally, e.g., ELY, supra note 9; Lain, supra note 11.

${ }^{13}$ See generally LEVINSON, supra note 11.

${ }^{14}$ There are, of course, exceptions. Paul Brest argues that conscientious legislators should regard themselves as more legally constrained than a court is prepared to demand of them. See generally Paul Brest, The Conscientious Legislator's Guide to Constitutional Interpretation, 27 STAN. L. REV. 585 (1975). Robin West urges progressives to turn from the "adjudicated Constitution" to the "legislated Constitution, the Constitution looked to by the conscientious legislator as he or she seeks to fulfill her political obligations." Robin West, The Missing Jurisprudence of the Legislated Constitution, in THE CONSTITUTION IN 2020 at 79 (Jack M. Balkin \& Reva B. Siegel 
Among academic constitutional lawyers, a role morality is widely deemed applicable to federal judges. That role morality is intended to discipline judges beyond strictly legal restraints on their behavior. ${ }^{16}$ Critically, however, judicial role morality is tied to a sense of the proper place of judges in the constitutional scheme. For example, legal scholars write that federal judges are supposed to possess reasons for their decisions and to offer them as justification for those decisions, at least most of the time. Judges are supposed to be relatively constrained in their decision-making and to proceed consistently and incrementally, at least most of the time. They are supposed to worry about the countermajoritarian difficulty, perhaps regardless of the truth value of Bickelian assertions. Judges are supposed to maintain the appearance (and reality) of impartiality. Particular judges are celebrated for having possessed sound judgment and practiced the virtue of statesmanship. When judges issue decisions to which Americans vigorously object, their objections are unlikely to be dismissed by constitutional law scholars with conversation stoppers like "appointments have consequences" or "it's just judging" to issue such decisions.

By contrast, academic constitutional lawyers do not generally write that a role morality should guide presidents and members of Congress. Following Bickel's contemporary, Herbert Wechsler, the field tends to view "politics" in America as an unprincipled realm in which elected

eds., 2009). Vicki Jackson defends the normative concept of "pro-constitutional" legislative representatives-that is, "representatives whose goals are to advance the purposes of constitutional democracy within their own constitutional system." Vicki C. Jackson, Pro-Constitutional Representation: Comparing the Role Obligations of Judges and Elected Representatives in Constitutional Democracy, 57 WM. \& MARY L. REV. 1717, 1717-18 (2015). Bruce Ackerman's theory of "constitutional moments" focuses on the role of the political branches in producing legitimate constitutional change and de-emphasizes the role of judges. See generally BrUCE AcKerman, We the People, Volume 1: Foundations (1991); Bruce Ackerman, We the People, Volume 2: Transformations (1998); Bruce Ackerman, We the People, Volume 3: The Civil Rights Revolution (2014). Akhil Amar's scholarship also does not focus mostly on courts, let alone the legitimacy of judicial review. See generally, e.g., AKHIL REED AMAR, AMERICA'S CONSTITUTION: A BIOGRAPHY (2005) [hereinafter AMAR, AMERICA'S Constitution]; AkHil Reed Amar, AmericA's Unwritten Constitution: The Precedents and Principles We Live By (2012) [hereinafter AMAR, AMERICA's UnWritTEn CONSTITUTION].

${ }^{15}$ It is impossible to prove such a claim. For suggestive quantitative evidence based on citation counts, see generally Fred R. Shapiro \& Michelle Pearse, The Most-Cited Law Review Articles of All time, 110 MicH. L. REV. 1483 (2012); Fred R. Shapiro, The Most-Cited Legal Books Published Since 1978, 29 J. LeGAL Stud. 397 (2000). For suggestive qualitative evidence, consider the Foreword to the Harvard Law Review, the journal Supreme Court Review, the focus of most constitutional law casebooks and courses on Supreme Court decisions, and the judicial focus of most of the most influential works of constitutional law and theory since Bickel wrote The Least Dangerous Branch. A non-exhaustive list includes Herbert Wechsler's famous "neutral principles" article, see infra note 17; John Hart Ely's process-oriented theory of judicial review, see generally ELY, supra note 9; Philip Bobbitt's famous modalities of constitutional argument, see generally BoBвiтT, supra note 8; Ronald Dworkin's work on legal interpretation, see generally, e.g., RONALD DWORKIN, LAW's EMPIRE (1986); David Strauss's theory of common law constitutionalism, see generally, e.g., DAVID A. STRAUSS, THE LIVING CONSTITUTION (2010); Cass Sunstein's theory of judicial minimalism in opinion writing, see generally CASS R. SUnSTEIn, ONE CASE AT A TiME: JUdicial MINIMALISM ON THE SUPREME COURT (1999); and the rise of first- and second-generation originalism, see generally Keith E. Whittington, Originalism: A Critical Introduction, 82 FordHAM L. Rev. 375 (2013). Even work on the Constitution outside the courts focuses more on the relationship of social movements to judicial review than on their relationship to the political branches. See generally, e.g., JACK M. BALKIN, LIVING ORIGINALISM (2011) [hereinafter BALKIn, Living Originalism]; Friedman, supra note 10; LARRY D. Kramer, The People ThemSelves: Popular Constitutionalism and Judicial Review (2005); MARK Tushnet, TAKInG THE Constitution Away from the COURTS (1999); Robert Post \& Reva Siegel, Roe Rage: Democratic Constitutionalism and Backlash, 42 HarV. C.R.-C.L. L. REV. 373 (2007).

\footnotetext{
${ }^{16}$ For a discussion of the claims made in this paragraph, see infra Part I.
} 
officials are free to exercise their wills to whatever extent formal electoral processes have vested in them the legal authority to do so. ${ }^{17}$ When Americans voice objections to the employment of partisan political power, most constitutional law scholars qua scholars are likely to just shrug and conclude that the U.S. Constitution has nothing to do with the matter.

There is a basic problem with the enduring hold of Bickelian thinking over constitutional law scholarship in the United States. Not only did Bickel internalize the conflicts of those who had struggled to reconcile their posture toward the judiciary during the New Deal with a world in which the subject matter of judicial decision-making had changed, ${ }^{18}$ but he also wrote less than a decade after Brown and before the political branches began enacting civil rights legislation aimed at disestablishing an apartheid social order. In such a period, the Court's legitimacy was perceived to be in question. ${ }^{19}$ It is thus understandable why Bickel would have been worried about the Court's potential countermajoritarianism, and about how to protect the Justices' articulation of constitutional principles from being warped by the need to maintain the public legitimacy of the Court. ${ }^{20}$ Of course, the conduct and legitimacy of the Supreme Court remains worthy of extended scholarly attention and critique today. But Bickel's time was very different from our own, and, as a result, so were his most acute anxieties.

Consider some contemporary causes for concern. Americans today appear to be suffering from a collapsed understanding of politics. Both culturally and conceptually, they increasingly find themselves acting based upon an account of politics that verges on animus toward, and deep distrust of, fellow Americans in the other political party. ${ }^{21}$ They tend to view politics as a realm in which people are entitled to indulge their ideological appetites to the full extent legality permits - they are free to take maximum advantage in every situation. Too often, citizens imagine the American polity as populated by individuals who are so fundamentally alien from them-so "other" - that they are more charitably disposed toward a hostile foreign power than toward members of the other political party. "Those people," the thinking seems to go, cannot

${ }^{17}$ Wechsler's distinction between the principled realm of judicial decision and the unprincipled realm of political decision still resonates among constitutional law scholars. See Herbert Wechsler, Toward Neutral Principles of Constitutional Law, 73 HARV. L. REV. 1, 15 (1959) (“[W] hether you are tolerant, perhaps more tolerant than I, of the ad hoc in politics, with principle reduced to a manipulative tool, are you not also ready to agree that something else is called for from the courts? I put it to you that the main constituent of the judicial process is precisely that it must be genuinely principled, resting with respect to every step that is involved in reaching judgment on analysis and reasons quite transcending the immediate result that is achieved.").

${ }^{18}$ See Friedman, supra note 2, at 160-61, 228-36.

${ }^{19}$ See, e.g., Robert C. Post, Constitutional Domains: Democracy, Community, Management 43 (1995) (“Brown represented a courageous gamble.").

${ }^{20}$ See BICKEL, supra note 6, at 111-98 (advocating that the Court deploy "the passive virtues," such as standing doctrine, to protect legal principles from being distorted by the necessity of preserving public legitimation).

21 See, e.g., Frank Bruni, I'm O.K.-You're Pure Evil, N.Y. TIMES (June 17, 2017), https:/www.nytimes.com/2017/06/17/opinion/sunday/im-ok-youre-pureevil.html?action=click\&pgtype $=$ Homepage \&clickSource $=$ story-heading\&module $=$ opinion-c-col-leftregion\&region=opinion-c-col-left-region \&WT.nav=opinion-c-col-left-region\&_r=0 ("If not physically then civically, we're in a dangerous place when it comes to how we view, treat and talk about people we disagree with. Ugly partisanship may not be new, but some of its expressions and accelerants are.").

${ }^{22}$ See, e.g., Charles J. Sykes, The Danger of Ignoring Alex Jones, N.Y. TIMES (June 17, 2017), https://www.nytimes.com/2017/06/17/opinion/sunday/the-danger-of-ignoring-alex- 
be permitted to win the next election, or make the next Supreme Court appointment, or have their most important values or interests accommodated in any way, because so much is perceived to be at stake. Americans who are on the losing end of the most recent "razor's edge" election feel something akin to estrangement from the federal government.

Meanwhile, the federal government itself is increasingly dysfunctional; more often than not, elected officials are unable to cooperate across party lines in order to execute the basic responsibilities of the federal government in the constitutional scheme. For example, a Democratic Senate ended the filibuster for lower federal court nominees in 2013 after alleging unprecedented Republican obstruction. ${ }^{23}$ A Republican Senate did the same for Supreme Court nominees in 2017 in order to overcome a Democratic filibuster of Republican nominee Neil Gorsuch. ${ }^{24}$ Senate Republicans so acted after holding Justice Antonin Scalia's seat open for roughly a year in order to prevent Democratic President Barack Obama from filling the vacancy by appointing Chief Judge Merrick Garland of the U.S. Court of Appeals for the D.C. Circuit. ${ }^{25}$ It remains to be seen whether it will again be possible to fill a vacancy on the Supreme Court when the same political party does not control both the White House and the Senate.

In the near term, at least, there seems little reason for optimism. For example, a Republican Senate recently approved highly consequential tax legislation without any Democratic input or even a single hearing, let alone the process that used to be followed: "multiple congressional hearings, proposed statutory language and detailed reports from the taxwriting committees, all prepared well in advance of any vote" and "with the assistance of [Joint Committee on Taxation] staff and with the input of Treasury Department experts." ${ }^{26}$ In addition, Republican President Donald J. Trump routinely flouts norms and conventions of proper governmental behavior that previously had constrained presidents of both parties. ${ }^{27}$ And the Democrats, for their part, recently held up urgent funding legislation in order to extract a deal

jones.html?action $=$ click\&pgtype $=$ Homepage\&clickSource=story-heading\&module $=$ opinion-c-col-leftregion\&region=opinion-c-col-left-region\&WT.nav=opinion-c-col-left-region ("We now have a politics deeply infused with paranoia and distrust not only of our institutions but also of one another.").

${ }^{23}$ See Jeremy W. Winters, In Landmark Vote, Senate Limits Use of the Filibuster, N.Y. TIMES (Nov. 21, 2013), http://www.nytimes.com/2013/11/22/us/politics/reid-sets-in-motion-steps-to-limit-use-of-filibuster.html.

${ }^{24}$ See Matt Flegenheimer, Senate Republicans Deploy "Nuclear Option" to Clear Path for Gorsuch, N.Y. Times (Apr. 6, 2017), https://www.nytimes.com/2017/04/06/us/politics/neil-gorsuch-supreme-courtsenate.html?_r=0.

${ }^{25}$ See Mike DeBonis, Judge Dashes Merrick Garland's Final, Faint Hope for a Supreme Court Seat, WASH. POST (Nov. 18, 2016), https://www.washingtonpost.com/news/powerpost/wp/2016/11/18/judge-dashesmerrick-garlands-final-faint-hope-for-a-supreme-court-seat/?utm_term=.b518d565f272.

${ }^{26}$ See, e.g., Edward Kleinbard, Senators Picked Americans' Pockets Via Degraded Tax Policy Process, THE HiLl (Dec. 4, 2017), http://thehill.com/opinion/finance/363096-senators-picked-americans-pockets-viadegraded-tax-process.

${ }^{27}$ For discussions, see generally Neil S. Siegel, Political Norms, Constitutional Conventions, and President Donald Trump. 93 InD. L.J. (forthcoming 2018); Daphna Renan, Presidential Norms and Article II, 131 HARV. L. REV. (forthcoming 2018). 
that would offer a path to citizenship to beneficiaries of the program known as Deferred Action for Childhood Arrivals (DACA); a shutdown of the federal government ensued. ${ }^{28}$

Three characteristics of the problems discussed above stand out. First, they mostly implicate the convictions and conduct of the public and the political branches, not the courts. Second, they concern mindsets and behavior that, while ostensibly troubling, are not potentially illegal. And third, that behavior, even where not illegal, raises concerns that are properly denominated constitutional in the broad sense that they appear to call into question the long-term health of the American constitutional system. Given the nature and potential magnitude of those problems, it is time for constitutional law scholarship in the United States to escape the shadow of Bickel's generation (and that of his teachers). To help address the problems of our situation, constitutional law scholars might follow the example of certain contemporary scholars of statutory interpretation by focusing a bit less on the judiciary and a bit more on the political branches. ${ }^{29}$ More specifically (and distinctively), constitutional law scholars might do for elected officials what they have long done for judges: contribute to the development of a constitutional role morality by identifying normative restraints on the discretion of politicians beyond the legal restrictions imposed by the Constitution and federal law. This Article is offered in that spirit. ${ }^{30}$

What are the sources of a constitutional role morality for presidents and members of Congress? Where is one to look for a role morality that demands more than compliance with the law writ small? Rather than consult a general theory of morality or a political theory of representation or political ethics, this Article focuses on the American constitutional system in particular and suggests two good places to look. The first is a particular understanding of the American commitment to democracy, which has implications not just for First Amendment doctrine but also for the role responsibilities of representatives. As illuminated by the writings or examples of Rousseau, Burke, Madison, Washington, and Jefferson, American representatives have a duty to represent the whole and not just the part in order to manage the tension between democracy and diversity in a strikingly heterogeneous political community that is nonetheless committed to the ideal of collective self-governance. Such a community must confront the question of how, and under what circumstances, electoral losers can fairly be thought of as selfgoverning. ${ }^{31}$ The second source of a constitutional role morality rests upon a particular understanding of the requirements of good institutional citizenship in a robust separation of

${ }^{28}$ See, e.g., Caitlin Dickerson, What Is DACA? Who Are the Dreamers? Here Are Some Answers, N.Y. TIMES (Jan. 23, 2018), https://www.nytimes.com/2018/01/23/us/daca-dreamers-shutdown.html.

${ }^{29}$ See generally, e.g., Abbe R. Gluck \& Lisa Schultz Bressman, Statutory Interpretation from the InsideAn Empirical Study of Congressional Drafting, Delegation and the Canons: Part I, 65 STAN. L. REV. 901 (2013); Abbe R. Gluck \& Lisa Schultz Bressman, Statutory Interpretation from the Inside-An Empirical Study of Congressional Drafting, Delegation and the Canons: Part II, 66 STAN. L. REV. 725 (2014).

${ }^{30}$ For the closest such effort, see generally Jackson, supra note 14. There are differences between Professor Jackson's wonderful Essay and this Article. For example, this Article emphasizes the problem of minority selfgovernance; articulates a role morality for both presidents and members of Congress; differently develops the contents of that role morality; and, most importantly, theoretically grounds a constitutional role morality for federal elected officials in specific purposes of the U.S. Constitution that legal rules alone cannot accomplish. Both pieces, however, "engage in a project central to the success of constitutional democracy - the normative reconstruction of representation." Id. at 1788 .

${ }^{31}$ For a discussion of this literature, see infra Part II.A. 
powers regime that is not intended to impair the ability of the federal government to function at least tolerably well and that, in an era of polarization and distrust, increasingly threatens it with dysfunction. On that view, it is critical to keep partisanship in the political branches within reasonable bounds so that the federal government can fill executive and judicial offices, solve multi-state collective action problems that the states cannot solve on their own, and protect civil rights. $^{32}$

Both sources of a constitutional role morality speak directly to the actual circumstances of contemporary American political life: high levels of political polarization and ill will threaten to render the tension between democracy and diversity impossible to reconcile, and to render the federal government incapable of executing its basic responsibilities. ${ }^{33}$ More fundamentally, both sources of a role morality constitute basic purposes of the Constitution-facilitating collective self-governance and creating a functional federal government-that require more than compliance with legal rules if they are to be vindicated. When presidents and members of Congress respect the restraints imposed by constitutional role morality, they help accomplish those constitutional purposes. A constitutional role morality for elected officials can be thought of as occupying normative territory at the border between law and politics as conventionally conceived - that is, between a realm of "hard" restraints on the exercise of discretion by elected officials, and a realm of unlimited discretion by such officials. Official conduct that disregards role restraints is anticonstitutional, even if it is not unconstitutional.

Specifying the contents of a constitutional role morality for elected officials poses a formidable challenge, in part because elections do and should have significant consequences for American governance. This Article nonetheless makes a preliminary attempt at identifying rhetorical, procedural, and substantive components of a role morality that can (modestly) limit the stakes of losing elections while still enabling the prevailing party to govern and the federal government to function effectively. ${ }^{34}$ The merits of the tentative proposals to follow, however, are not critical at this point. This Article is primarily concerned with starting a normative conversation, with showing that it is an important conversation, and with suggesting that constitutional law professors (in addition to other legal scholars) are at least apt participants in such conversations.

Constitutional law scholarship that develops the idea of a role morality for members of the political branches will have implications for how different actors in the American constitutional system ought to execute their own responsibilities if they are to make it more, rather than less, likely that such a role morality will eventually be adopted and maintained. ${ }^{35}$ Most obviously, politicians who are tempted to exercise partisan power in aggressive ways should consider not simply the legal authority that vests as a consequence of formal electoral processes, but also their potential obligations to represent the whole and not just the part, and to

${ }^{32}$ For development of this argument, see infra Part II.B.

${ }^{33}$ See, e.g., Philip Bump, Political Polarization Is Getting Worse. Everywhere, WASH. Post (Apr. 9, 2016), https://www.washingtonpost.com/news/the-fix/wp/2016/04/09/polarization-is-getting-worse-in-every-part-ofpolitics/?utm_term=.f8ba11e60d0b.

\footnotetext{
${ }^{34}$ For a discussion, see infra Part III.B.

${ }^{35}$ For development of those points, see infra Part IV.
} 
help the system function better and not worse. Although most politicians may be unlikely to practice normative self-restraint very often in the short-to-medium run, investing in civic education (contra current trends) could eventually have a positive impact on the constituents, donors, party officials, media outlets, and others who constitute the environment in which elected officials must function. And law teachers might consider operating within a longer time horizon and developing ways to instruct their students - in their capacities as future politicians, not just future judges - that a role morality applies to their own conduct. Law teachers might also engage their students as citizens, as well as future lawyers, and instruct them that high levels of polarization and animus between members of the two main political parties imperil the constitutional system.

In the shorter term, there may be an implication for practices of political resistance. Few would accept aggressive judicial behavior lying down just in virtue of asserted justifications that "appointments have consequences" or "it's just judging" for Supreme Court Justices to advance ideological agendas. Likewise, opposition politicians, members of the news media, the institutions of civil society, and concerned citizens need not simply accept assertions by those in power (or their supporters) that "elections have consequences" or that "it's just politics" for elected officials to forcefully advance ideological agendas. Nor ought the opposition to limit its pushback to considering whether a president is "legitimate" or whether a president has a "mandate" to govern. Instead, the opposition should feel entitled to speak the language of constitutional legitimacy to exercises of partisan power when politicians act as if they owe nothing to Americans who did not vote for them and to the institutions in which they serve.

Part I discusses the longstanding concern of constitutional law scholars with judicial role morality. Part II looks to the American commitment to democracy and the American constitutional structure for normative sources of a role morality for elected officials. Part III offers a preliminary sketch of the obligations of elected officials as part of their role morality. Part IV identifies role implications for politicians, law teachers, and Americans who oppose aggressive action by an administration or Congress. Part V anticipates objections.

Before proceeding, two clarifications are in order. First, although this Article argues for role restraints on elected officials to combat extreme partisanship, it is important to bear in mind that, if the argument were accepted, politicians would still retain the ability to pursue various objectives consistent with their role morality, including goals they should feel morally obliged to accomplish for others. ${ }^{36}$ A constitutional role morality for elected officials should not be viewed as mostly constraining, any more than it should be so viewed for judges. Moreover, this Article will show that a constitutional role morality for politicians opens up new possibilities for more responsive and effective governance.

Second, solutions to the problems of polarization in contemporary American politics obviously depend upon their causes. Because this Article does not examine those causes, it does not offer short-to-medium run solutions beyond civic education, which cannot hurt and might eventually help. Instead, the Article provides a normative account that can be discussed and debated on its own terms. If enough Americans find it attractive, solutions will come in time.

\footnotetext{
${ }^{36}$ See generally, e.g., West, supra note 14 (emphasizing the obligations of the conscientious legislator).
} 


\section{Judicial Role Morality}

The efforts of constitutional law scholars to develop a role morality for judges, one that it linked to the perceived place of judges in the constitutional scheme, are sufficiently numerous and familiar that they risk not being recognized as related and as having that purpose. Those efforts may be described as a multi-generational scholarly and professional project of emphasizing constraining conceptions of a judge's institutional role. Such conceptions are of course thought to include legal restraints on judicial conduct - for example, legal prohibitions on taking bribes or adjudicating cases when a judge's impartiality might reasonably be questioned or when specific kinds of bias, prejudice, or conflicts of interest can be shown to exist in fact. ${ }^{37}$ But conceptions of judicial role are thought to impose more than just legal restraints on judges. Concerns about unduly assertive judicial conduct have caused constitutional law scholars and other members of the legal community to develop and advocate for operational limits on how judges exercise their discretion.

Notably, proposed limits do not characteristically take the form of hard-edged legal claims. For example, one does not typically hear assertions to the effect that "it would be illegal for a judge to cast a vote against the constitutionality of a statute because she thinks the statute is bad policy." Instead, one tends to encounter a number of important ideas that sound in a different register. As noted above, constitutional law scholars have long insisted that Supreme Court Justices face a "countermajoritarian difficulty," 38 and their insistence may play a role in limiting judicial discretion regardless of the truth value of the proposition. In addition, commentators emphasize the importance of judicial reason giving. ${ }^{39}$ They propose ways of disciplining judges to the virtue of consistency and securing related rule-of-law values from judicial decision making. ${ }^{40}$ They endorse particular approaches to constitutional interpretation and reject others based in part upon concerns about proper judicial role. ${ }^{41}$ They insist on basic fairness to litigants. ${ }^{42}$ They criticize judges who they do not believe are maintaining an appearance or reality of impartiality off the bench. ${ }^{43}$ They advise judges to proceed incrementally. ${ }^{44}$ They defend the

${ }^{37}$ See 28 U.S.C. $§ 455$ (2012) (identifying circumstances in which judicial recusal is required).

${ }^{38}$ See supra notes 6-9 and accompanying text.

${ }^{39}$ See generally, e.g., Frederick Schauer, Giving Reasons, 47 STAN. L. REV. 633 (1995).

${ }^{40}$ See, e.g., Robert C. Post \& Neil S. Siegel, Theorizing the Law/Politics Distinction: Neutral Principles, Affirmative Action, and the Enduring Legacy of Paul Mishkin, 95 CALIF. L. REV. 1473, 1500 (2007) (discussing how best to "advance the goal of disciplining judges to the virtue of consistency").

${ }^{41}$ See generally, e.g., BoBBITT, supra note 8 (identifying the kinds of arguments that participants in American constitutional discourse, especially judges, conventionally employ).

${ }^{42}$ See, e.g., Edward B. Foley, Due Process, Fair Play, and Excessive Partisanship: A New Principle for Judicial Review of Election Laws, 84 U. CHI. L. REV. 655, 686-93 (2017) (discussing the principle of “fair play").

${ }^{43}$ See, e.g., Jeffrey Toobin, How Badly Is Neil Gorsuch Annoying the Other Supreme Court Justices?, NEw YORKER (Sept. 29, 2017), https://www.newyorker.com/news/daily-comment/how-badly-is-neil-gorsuch-annoyingthe-other-supreme-court-

justices?mbid=nl_170930_Daily\&CNDID=48074089\&spMailingID=12041378\&spUserID=MTczODY1MTk3OD M1S0\&spJobID=1242559629\&spReportId=MTI0MjU1OTYyOQS2 (criticizing the speech Justice Gorsuch gave to a conservative group at the Trump International Hotel in Washington, D.C., and the speech he delivered at the University of Louisville, where he was introduced by Senate Majority Leader Mitch McConnell). Justice Ginsburg was also criticized for her comments about President Trump when he was the Republican nominee. See, e.g., 
idea of "judicial restraint." 45 They expect judges to respect institutional norms of appropriate judicial conduct. ${ }^{46}$ They criticize judges who behave in an intemperate fashion. ${ }^{47}$ They underscore a number of judicial virtues - a sense of proportion, the practice of moderation, the exercise of sound judgment, and the possession of good timing and tact - that fall under the general heading of judicial statesmanship, which counsels judges to take some account of the conditions of a court's own public legitimacy. ${ }^{48}$ Commentators also condemn judicial willfulness or "activism" - that is, unjustifiably assertive judicial decision making. ${ }^{49}$

Few members of the legal community would recommend any of the foregoing ideas always or invariably. On the contrary, commentators proffer a variety of presumptions, exceptions, and countervailing considerations. To take the most obvious example, almost no one is prepared to argue that Brown v. Board of Education was wrongly decided, and Brown was of course not an exemplar of judicial restraint. ${ }^{50}$ Even so, commentators frequently urge constraining ideas upon judges. What is more, they do so notwithstanding a lack of consensus about which ideas to push, both at a particular time and over time. Legal scholar Craig Green underscores the disagreements over judicial role that continuously unfold in history:

[V]igorous debates over judicial role continue because judicial norms are flexible and change over time. Each new crop of judges, lawyers, and scholars must learn, experience, and consider issues of judicial role for themselves. At any point in time, certain notions of judicial role will be dominant, others subordinate, and others mired in competitive struggle. The legal community's unending

Editorial, Justice Ginsburg's Inappropriate Comments on Donald Trump, WASH. Post (July 12, 2016), https:/www.washingtonpost.com/opinions/justice-ginsburgs-inappropriate-comments-on-donaldtrump/2016/07/12/981df404-4862-11e6-bdb9-701687974517_story.html?utm_term=.364c6e5b79be.

${ }^{44}$ See generally, e.g., SUNSTEIN, supra note 15 (articulating a theory of judicial minimalism in opinion writing).

${ }^{45}$ See generally, e.g., Thomas W. Merrill, Originalism, Stare Decisis, and the Promotion of Judicial Restraint, 22 CONST. COMMENT. 271 (2005) (arguing for a strong theory of judicial precedent on grounds of judicial restraint).

${ }^{46}$ See, e.g., Curtis A. Bradley \& Neil S. Siegel, Historical Gloss, Constitutional Conventions, and the Judicial Separation of Powers, 105 GeORGETOWN L.J. 255, 319-21 (2017) (discussing how the concepts of historical gloss and constitutional conventions relate to questions of judicial independence and power).

${ }^{47}$ For example, Justice Scalia, for all his gifts and influence, was capable of writing with a nastiness that arguably served neither himself nor the Court nor the country well. See, e.g., Obergefell v. Hodges, 135 S. Ct. 2584, 2630 (2015) ("If, even as the price to be paid for a fifth vote, I ever joined an opinion for the Court that began [how the majority opinion does], I would hide my head in a bag.").

${ }^{48}$ See generally, e.g., Neil S. Siegel, The Virtue of Judicial Statesmanship, 86 TEX. L. REV. 959 (2008) (theorizing the phenomenon of judicial statesmanship and its relationship to professional legal reasoning); Robert Post, Theorizing Disagreement: Reconceiving the Relationship between Law and Politics, 98 CALIF. L. REV. 1319 (2010) (similar).

${ }^{49}$ See generally Craig Green, An Intellectual History of Judicial Activism, 58 EMORY L.J. 1195 (2009). For a critique of how motivated political actors deploy activism rhetoric to mask substantive objections in process objections, see generally Neil S. Siegel, Interring the Rhetoric of Judicial Activism, 59 DEPAUL L. REV. 555 (2010). Although it is important to call out manipulative use of activism rhetoric, such rhetoric can help fashion role restraints on judges.

50347 U.S. 483 (1954). 


\section{participation in cultural contests over judicial role is an under-appreciated precondition of our system of judicial discretion within limits. ${ }^{51}$}

Disagreement about which restraints to impose has not simply undermined the project of persuading federal judges to respect the limits of their appropriate role in the constitutional scheme. Disagreement has also helped construct the very role constraints whose contents are in question. Disagreement has also validated the general idea that such restraints exist.

Constitutional law scholars, as well as law teachers more generally, seek to bring the above ideas closer to reality in a variety of ways. In their writing, they develop principles for judges to consider. They mobilize histories of judges who are thought to have exemplified good judging. ${ }^{52}$ They identify judicial decisions that form part of the legal "canon." 53 They critique judicial decisions that fall short of proposed principles, including decisions that they identify as anticanonical. ${ }^{54}$ They challenge their students (future judges among them) to consider what good and bad judging looks like in a variety of settings. In all of those efforts, judicial biographies and judicial decisions serve as case studies of success or human frailty in executing the responsibilities of the judicial role. ${ }^{55}$ And judges themselves serve as educators by teaching lessons about judicial role to their law clerks, ${ }^{56}$ some of whom will go on to become judges. ${ }^{57}$

${ }^{51}$ Craig Green, What Does Richard Posner Know About How Judges Think?, 98 CAL. L. REV. 625, 661-62 (2010) (emphasis added) (reviewing RichARD POSNER, HOW JUDGES THINK (2008)).

${ }^{52}$ See generally, e.g., G. EdWARd White, The American Judicial Tradition: Profiles of Leading AMERICAN JUDGES (3rd ed. 2007); Green, supra note 51, at 627 (“As White's book illustrates, judicial methods emerge from complex interactions among society, politics, and biography. Thus, the strongest determinants of how judges think may be the historical stories and principles through which the legal community celebrates judicial heroes and triumphs, while condemning villains and failures.").

${ }^{53}$ See generally, e.g., J.M. Balkin \& Sanford Levinson, The Canons of Constitutional Law, 111 HARV. L. REV. 964 (1998) (calling for a revitalized constitutional canon, one that is less centered on decisions of the U.S. Supreme Court).

${ }^{54}$ See, e.g., Jamal Greene, The Anticanon, 125 HARV. L. REV. 379, 379 (2011) (defining the "anticanon" as "the set of cases whose central propositions all legitimate decisions must refute").

${ }^{55}$ See Green, supra note 51, at 646 ("Our history-laden system of legal education places questions of judicial role front and center, especially in cases that are nonroutine. Even as future judges (i.e., law students) learn the content of historical cases and rules, these same episodes yield instructive examples of proper judicial conduct and methods." (footnote omitted)).

${ }^{56}$ Notably, the ethics guide that the Federal Judicial Center prepares for law clerks is framed in terms of "maintaining the public trust." See Federal Judicial Center, Maintaining the Public Trust, Ethics for Federal Judicial Law Clerks 1 (4th ed. 2013), https://www.fjc.gov/sites/default/files/2017/Maintaining-Public-Trust-4D-FJC-Public2013.pdf ("The parties and the public accept judges' rulings because they trust the system to be fair and impartial. Maintaining this trust is crucial to the continued success of our courts."). I thank Marin Levy for this reference.

${ }^{57}$ See, e.g., John Fabian Witt, The Secret History of the Chief Justice's Obamacare Decision, in THE Health Care Case: The Supreme CourT's Decision and ITS Implications 215-216 (Nathaniel Persily, Gillian E. Metzger \& Trevor W. Morrison eds., 2013) (arguing that Justice Brandeis instilled his broad view of Congress's taxing authority in his law clerk Henry Friendly, who in turn instilled it in his law clerk John Roberts, so that "[t]he tax power strand in Roberts's Obamacare opinion was made available by a professional culture of lawyers stretching back into the beginnings of the modern state"). Witt concludes that "[1]aw is located, in part, in the professional identities of the men and women who make it." Id. at 222. 
It is likely impossible to know - to determine empirically-how much of a long-term effect such ideas and the rhetoric associated with them have had or can have on judicial behavior. Court watchers who believe that the Justices are extraordinarily self-confident and assertive regardless of what others think may be inclined to doubt the efficacy of those methods. Much depends on the individual judge - for example, the extent to which he or she is attuned to potential threats to the Court's institutional legitimacy and is prepared to take steps to preserve it. Yet it may be telling that constitutional law scholars (and the broader legal culture) keep generating such constraining conceptions; perhaps that would not keep happening if they made no difference at all. Those who have worked for judges or who interact with them in other ways are often left with the impression that most of them worry about staying within their limited institutional role even if they do not always seem to do so. And even such assertive, recent interventions as Shelby County v. Holder ${ }^{58}$ and Obergefell v. Hodges ${ }^{59}$ were actually culminating events; the judicial majorities that produced them proceeded incrementally and with apparent attention to the views of other actors. ${ }^{60}$

More generally, it is easy to lose sight of the profoundly important questions that modern federal judges (whether named Garland or Gorsuch) will not decide assertively or at all, including matters of war and peace, the direction of federal fiscal or monetary policy, and the continued operation of various hard-wired provisions of the Constitution. Although Supreme Court Justices no doubt possess a great deal of power in modern America, they have not, on the whole, used their power to unwind all or most of the work of the political branches. That is not because anything in the Constitution or federal law somehow forcibly prevents them from doing so. Rather, it is because scholars, the public, and the Justices themselves have all internalized some relatively strong ideas about how federal judges ought to behave in the American constitutional system.

None of that is to suggest, however, that concerns about efficacy are unreasonable. They are reasonable. Even so, it has seemed worthwhile to a great many constitutional law scholars to cultivate a culture of role constraints on judges. The balance of this Article will argue that it is similarly worthwhile to develop a role morality for presidents and members of Congress, even if concerns about efficacy are even more acute in the context of the political branches. ${ }^{61}$ The next Part suggests that the success of the American constitutional project depends in part upon elected officials who understand the normative limits of their institutional roles.

${ }^{58} 133$ S. Ct. 2675 (2013).

${ }^{59} 135$ S. Ct. 2584 (2015).

${ }^{60}$ See Nw. Austin Mun. Util. Dist. No. One v. Holder, 557 U.S. 193 (2009) (precursor to Shelby County); United States v. Windsor, 133 S. Ct. 2675 (2013) (precursor to Obergefell); see also generally Neil S. Siegel, Federalism as a Way Station: Windsor as Exemplar of Doctrine in Motion, 6 J. LEGAL ANALYSIS (2014) (analyzing the potential reasons for the Court's unusual opinion in Windsor); Neil S. Siegel, Reciprocal Legitimation in the Federal Courts System, 70 VAND. L. REV. 1183 (2017) (discussing the interaction between the Supreme Court and the lower federal courts beginning in Windsor and ending in Obergefell).

${ }^{61}$ This Article does not argue that the same role morality applies to judges and politicians. They occupy different institutional roles. For example, judges likely have greater obligations of reason giving and consistency than do elected officials, because judges have special obligations to maintain the rule of law and legislators (who have many more colleagues than judges) must often compromise to get anything done. 
A predictable objection to the idea that role restraints beyond legal fidelity attach to political office, just as they apply to judicial office, is that the judicial analogy is misguided because such restraints apply only to countermajoritarian institutions and the political branches are majoritarian. That way of thinking is, of course, part of what Bickel, his teachers, and his contemporaries bequeathed to subsequent generations of constitutional law scholars. One response is that the federal electoral system has countermajoritarian components that are both numerous and severe, ${ }^{62}$ as does the federal policymaking process. ${ }^{63}$ Those components can produce presidents and parties in control of Congress that lack majority or plurality support in the nation for their elections and priorities.

Another response is that the objection is misguided even on its own terms because a constitutional role morality is important for members of institutions that attract majority support. Consider initially the case of judges. The Supreme Court tends to be a more majoritarian institution than Bickel ever imagined, and yet (or is it because?) a role morality is widely thought applicable to the conduct of the Justices, including when they possess majority support for their decisions. Moreover, the Justices are expected to respect role restraints when they decide cases not requiring constitutional judicial review, such as those involving statutory interpretation.

Likewise, one should not conclude that a constitutional role morality is inapplicable to the conduct of elected officials when they possess majority support for the decisions. As explained in the next Part, realizing the ideal of democracy as collective self-governance does

${ }^{62}$ Countermajoritarian aspects include the malapportionment of the Senate, the Electoral College method of electing the president, gerrymandering aided by computer technology, the more efficient distribution of Republican voters around the nation, and a federal statute that requires single-member congressional districts. For discussions of political branch countermajoritarianism, see supra note 11 and accompanying text; Nate Cohn, Why Democrats Can't Win the House, N.Y. TIMES (Sept. 6, 2014), https://www.nytimes.com/2014/09/07/upshot/why-democratscant-win.html (explaining why "clustering" of Democrats in urban areas impedes the ability of the Democratic Party to gain control of the House even when the party enjoys a national political majority); Emily Badger, As American as Apple Pie?: The Rural Vote's Disproportionate Slice of Power, N.Y. TIMES (Nov. 20, 2016), https://www.nytimes.com/2016/11/21/upshot/as-american-as-apple-pie-the-rural-votes-disproportionate-slice-of-

power.html (discussing the effects of rural favoritism in the constitutional structure on the outcomes of elections for president, House seats, and Senate seats); AMAR, AMERICA's UnWritTEN CONSTITUTION, supra note 14, at 413 (noting that "[s]ince 1967, the single-member-district statute has been a fixed feature of the U.S. election code"). One should add low voter turnout, the fact that Americans who vote are whiter, older, and wealthier than the population as a whole, and the imposition of voting restrictions despite no credible evidence of a significant problem of in-person voter fraud. For discussions, see Lain, supra note 11, at 154, and LORRAINE C. MinNITE, THE MYTH OF VOTER FRAUD (2010).

${ }^{63}$ Countermajoritarian aspects include the bicameralism and presentment requirements, the latter of which grants veto power to the president. U.S. CONST. art. I, $§ 7, \mathrm{cl}$. 2. Congressional rules and practices, as well as political dynamics, also add to the countermajoritarian characteristics of the federal policymaking process. See LEVInson, supra note 11, at 52-53 (discussing the Senate filibuster); THOMAS E. MANN \& NoRMAN J. ORnSteIn, The Broken Branch: How Congress Is Failing America And How to Get It Back on Track 45 (2006) (observing that "independent, unrepresentative, and constituency-controlled committees can distort legislative outcomes and frustrate chamber majorities and national interests"); Richard L. Hasen, Three Wrong Progressive Approaches (and One Right One) to Campaign Finance Reform, 8 HARV. L. \& POL'Y REV. 21, 33 (2014) (arguing that "large donors, lobbyists, and others who bundle contributions are able to obtain much broader access than others to legislators and staffers to make the case for legislative action (or inaction)" and that "[a]ccess does not guarantee legislative success, but it is usually a prerequisite"); Mark A. Graber, The Countermajoritarian Difficulty: From Courts to Congress to Constitutional Order, 4 ANN. REV. L. \& Soc. SCI. 361 (2008) (concluding that "countermajoritarian policymaking is being enabled by almost every trend in American politics"). 
not depend upon whether elected officials earn majority backing. In today's America, for example, even when a president is elected by a popular majority, a large percentage of the population is likely to oppose his or her priorities. As also explored below, ensuring the basic functionality of the federal government does not turn on whether the institutions controlled by politicians are best described as majoritarian. For example, the appointments and legislative processes can grind to a halt or otherwise leave much to be desired when different politicians who control different veto gates were each elected by different popular majorities.

As will be discussed, role restraints on both judges and elected officials may well loosen up when supermajorities of Americans support their proposed decisions. ${ }^{64}$ For example, given recent and dramatic changes in public sentiment regarding the permissibility of same-sex marriage, the Court's decision in Obergefell v. Hodges may have been more justifiable in 2015 than it would have been in 2005 or $1995 .{ }^{65}$ Likewise, a president who enjoys 70 percent support may possess a special democratic warrant to act within the bounds set by the law (which includes respect for individual rights). But that is a far cry from the suggestion that countermajoritarianism exhausts the circumstances in which a role morality applies to elected officials.

Perhaps the objection could be reframed by turning from the question of whether the institution under consideration is countermajoritarian to whether its members are elected. On that view, a constitutional role morality applies only if members of the institution are unelected, like federal judges, and not when they are elected, like presidents and members of Congress. It is not clear, however, why elections should make a decisive difference. It has just been noted that winning a federal election does not necessarily confer upon a president or member of Congress a majoritarian democratic warrant to act. Moreover, elected state judges are not generally thought to be unencumbered by a constitutional role morality, even if they may be less or differently encumbered. ${ }^{66}$ One may applaud or decry the greater political accountability of state judges relative to federal judges, but the way state judges typically act in court, the various procedures they are required to follow, and the ways they are expected to justify their decisions are more similar to federal judges than different. Most importantly, holding elections does not resolve the problems discussed below: securing both collective self-governance and a well-functioning federal government. At most, the greater level of accountability associated with elections (as

${ }^{64}$ See infra note 188 and accompanying text (discussing the case of elected officials who enjoy supermajority support over a sustained period of time to make significant legal and political change).

65135 S. Ct. 2584 (2015). This Article does not engage the complex questions of whether and when changes in public opinion potentially justify particular judicial interpretations of the Constitution. Public opinion may be relevant as part of the best living constitutionalist understanding of what a constitutional provision means, or because statesmanship previously counseled against the expression of the best understanding. For work in the former category, see generally Lain, supra note 11. For work in the latter category, see supra note 48, infra note 160 , and accompanying text.

${ }^{66}$ According to David Pozen, the fact that many state judges are popularly elected or retained potentially changes what role fidelity demands of them, so that it is inappropriate to apply to them normative models that presuppose the life tenure of federal judges. See David E. Pozen, Judicial Elections as Popular Constitutionalism, 110 COLuM. L. REv. 2047, 2083-86 (2010) ("The notion of majoritarian review . . . holds out the possibility that courts should flexibly interpret the law to reflect the contemporaneous beliefs of the people. The notion of role fidelity, furthermore, holds out the possibility that elected courts have special license to do this."). 
opposed to life tenure) suggests that elected officials should be less restrained by a constitutional role morality than are federal judges, not that politicians should not be restrained at all.

\section{SOURCES OF Constitutional Role Morality}

Why should elected officials owe anything to their political opponents, or to the nation as a whole, or to the institutions in which they serve? Framed more precisely, what are sources of a constitutional role morality for the elected officials of the national government? This Part locates those sources in two basic purposes of the Constitution whose accomplishment requires more than compliance with legal rules. ${ }^{67}$ The first is vindicating the American commitment to democracy as collective self-governance. What is needed to achieve that purpose is illuminated by longstanding thinking in democratic theory-thinking that was reflected in the words and deeds of prominent American Founders and early Presidents - about the duty of representatives to represent the whole and not just the part. The second purpose is creating a reasonably wellfunctioning federal government. Accomplishing that purpose in a robust separation of powers regime requires politicians to keep partisanship within reasonable bounds by practicing good institutional citizenship.

Before proceeding, it is worth addressing an objection at the outset. The literature on political representation in normative and positive political theory is so robust and varied that one might question what constitutional law scholars could possibly add to academic discussions about the role responsibilities of elected officials. ${ }^{68}$ This Article provides one answer to that question by doing what the political theory literature characteristically does not do: draw upon a judicial analogy and tie arguments about the roles of the president and members of Congress in particular (as opposed to representatives more generally) to claims about the success of the American constitutional project in particular (as opposed to democracy or constitutional democracy more generally). What is required to sustain the U.S. Constitution in history is a subject to which academic constitutional lawyers can lay at least as much claim as political scientists. Adequately addressing the problem requires intimate familiarity with the American constitutional structure as specified in the text of the Constitution, as built out over time by elected officials, and as interpreted by the federal courts. Meeting the problem also requires an understanding of the functions that the Constitution exists to fulfill. Indeed, the participation of constitutional law scholars in scholarly discussions of the problem may be essential: it would be difficult to fully address the relationship between official roles and the constitutional project without a deep appreciation of the Constitution as law.

${ }^{67}$ There are, of course, other constitutional purposes, and law alone is likely insufficient to accomplish them. Rather than attempt to be comprehensive, this Article focuses on two such purposes that are under especially severe stress in current, polarized times.

${ }^{68}$ The most influential modern work is HANnA PitKin, THE CONCEPT OF REPRESENTATION (1967). For an overview of the literature, see Suzanne Dovi, Political Representation, Stan. EnCyClopedia PhIL. (Jan. 6, 2017), https:/plato.stanford.edu/archives/win2017/entries/political-representation/. For useful essays, see POLITICAL REPRESENTATION (Ian Shapiro et al. eds., 2010). For further discussion of the literature, see infra notes 97-100. For additional citations to the literature, see Jackson, supra note 14, at 1749 n.87. 


\section{A. A Substantive Conception of Democracy}

Americans are committed to democracy as their ideal form of government, but what does that commitment entail? A persuasive substantive understanding of American democracy can be found in Frank Michelman's emphasis on democracy as "self-rule," the conviction that "the American people are politically free insomuch as they are governed by themselves collectively." ${ }^{69}$ Democracy as collective self-rule-collective self-governance-cannot persuasively be cashed out in terms of a simple voting procedure (like majority rule) that determines electoral winners and losers. On such a conception of democracy, there seems no good answer to the question of how electoral losers can be said to govern themselves when electoral winners impose their will on them.

"A central problem of collective self-government that goes back at least to Rousseau," Robert Post writes, "revolves around the question of how, in the face of manifest and indissoluble differences, we may be said to govern ourselves through collective selfdetermination." 70 "Why," Post asks, "is every majoritarian enactment not also an act of oppression against a minority?", Rousseau was more helpful in framing the question than in formulating an attractive answer. His idea was that, after a process of majoritarian decisionmaking, the individual will of each citizen would be merged with the general will of all, so that, in obeying the general will, each citizen will "obey only himself and remain as free as before., ${ }^{, 2}$ Rousseau did not adequately grapple with the stubborn fact of political disagreement when citizens are free to express their convictions and pursue their interests. ${ }^{73}$

In more recent times, a wide range of democratic theorists has more plausibly posited that a feeling of self-governance can be instilled in citizens when electoral winners and losers alike are free to participate in the formation of public opinion to which electoral politics and subsequent policymaking are subservient. On that view, "the normative essence of democracy is ... located in the communicative processes necessary to instill a sense of self-determination, and in the subordination of political decision-making to these processes." ${ }^{, 74}$ Identifying collective

${ }^{69}$ Frank Michelman, Law's Republic, 97 YALE L.J. 1493, 1500-01 (1988).

${ }^{70}$ Robert C. Post, Democracy, Popular Sovereignty, and Judicial Review, 86 CALIF. L. Rev. 429, 433 (1998).

${ }^{71} I d$.

72 Jean-Jacques Rousseau, The Social Contract and other Later Political Writings 49-50 (Victor Gourevitch ed., 1997) (1762).

${ }^{73}$ In writing those (in)famous words, Rousseau was referring to fundamental decisions of the "sovereign" people, which set the basic terms of the political community for all its members. He was not referring to acts of the "government" (including, in the United States today, the courts), whose more mundane role is to administer the fundamental law previously approved by a majority of the people. For a discussion of the distinction between "sovereignty" and "government" developed by Hobbes, Rousseau, and other political theorists, see generally David Singh Grewal \& Jedediah Purdy, The Original Theory of Originalism: A Review of Richard Tuck's The Sleeping Sovereign, 127 YALE L.J. (forthcoming 2018). This Article is concerned with decisions that Rousseau would categorize as acts of government, not sovereignty. Even (or, perhaps, especially) at the level of sovereignty, however, it is not clear how majority rule produces self-rule by citizens who are outvoted.

${ }^{74}$ Post, supra note 19, at 185. See id. at 184-86 (discussing the theorizing of Rousseau, Hans Kelsen, Benjamin Barber, John Dewey, Durkheim, Jürgen Habermas, and John Rawls). A potential ambiguity in the theorizing of dialogic theorists of democracy is whether there is a fact of the matter regarding whether citizens are 
self-governance (and not a voting procedure like majority rule) as "the normative essence of democracy" helps explain why the modern Supreme Court describes the First Amendment "as the guardian of our democracy," 75 even though the Court wields free-speech principles as authority for instructing some popular or legislative majority that it cannot govern just as it wishes. As Post writes, "[t]he Amendment serves to limit majoritarian enactments, so 'democracy' cannot in this context be equated with simple majoritarianism." "In fact," Post continues, "majoritarianism, from the perspective of traditional First Amendment doctrine, is merely a mechanism for decision-making that we adopt to reflect the deeper value of selfgovernment ....,

It is unlikely, however, that First Amendment doctrine alone can fully accomplish the constitutional purpose of securing collective self-governance. As vital as the freedom to communicate on political matters is, it may go only so far in instilling in electoral losers a genuine sense of self-determination. Especially in a polarized community in which a great deal is perceived to turn on which political party wins each and every election, subordinating governmental decisionmaking to the communicative processes protected by the Amendment may not be enough to manage the tension between democracy and diversity. A potential democratic virtue of judicially enforceable individual rights - beyond protections for speech and voting - is that they take certain fundamental matters off the table for reconsideration at each election, thereby permitting electoral losers to retain a sense of self-governance at least to some extent. ${ }^{78}$

But just as participation in the formation of public opinion may not suffice for electoral losers to experience themselves as self-governing, neither may rights protections. Citizens possess a variety of interests and commitments that they regard as profoundly important indeed, potentially more important than some of the rights they enjoy. And those interests are potentially fair game in the political process. What may also be required for a political regime of electoral winners and losers to more genuinely approximate the American ideal of collective self-governance is an internalized sense among elected officials that they owe something not only to citizens who voted for them, but also to those who voted against them and to the polity as a whole - that, in virtue of having won the previous election, they have assumed some responsibility to look after not just the interests and values of their supporters, but also of their political opponents and of the entire nation.

ruling themselves, or whether the self-governance about which dialogic theorists write is instead a matter of what citizens tell themselves. While the latter possibility may suffice for the sociological legitimacy of a political regime (that is, legitimacy conceived of as a psychological willingness to assent to state force), actual normative legitimacy (that is, legitimacy according to some higher vision of constitutional democracy as a picture of part of the good life) probably requires some minimum threshold of actual self-governance in order to avoid the damning objection that citizens are driven to storytelling so that they can live under the pleasing illusion of self-rule.

${ }^{75} I d$. at 272 ("Every interpretation of the traditional First Amendment doctrine is, of course, contestable, but there is little dispute that one of the most important themes of that doctrine is the Amendment's function 'as the guardian of our democracy."”) (citing, inter alia, Brown v. Hartlage, 456 U.S. 45, 60 (1982)).

${ }^{76} I d$.

${ }^{77} I d$.

${ }^{78}$ On the other hand, judicial protections will further undermine the self-governance of electoral losers when they believe that courts wrongly withdraw important matters from the realm of democratic debate and decide them incorrectly. 
Such a constitutional role morality is supported by Edmund Burke's general conception of the duty of a legislator, which he articulated in his famous Speech to the Electors of Bristol. ${ }^{79}$ He delivered the speech at the conclusion of the 1774 election, in which he was chosen to serve as one of two representatives of Bristol in the House of Commons. ${ }^{80}$ The other successful candidate, Henry Cruger, had endorsed the right of constituents to instruct representatives on how to vote in Parliament. ${ }^{81}$ In response, Burke rejected such mandatory "instructions," as they were called. ${ }^{82}$

Given the issue that prompted the speech, Burke had no occasion to address the responsibility of legislators vis-à-vis those who did not vote for them. But his general statement regarding the role of a representative has implications for that issue. "Facing his constituents, both those who had voted for him and those who had not, ${ }^{, 83}$ Burke emphasized the duty of members of Parliament to represent the whole and not just the part:

Parliament is not a congress of ambassadors from different and hostile interests; which interests each must maintain, as an agent and advocate, against other agents and advocates; but parliament is a deliberative assembly of one nation, with one interest, that of the whole; where, not local purposes, not local prejudices, ought to guide, but the general good, resulting from the general reason of the whole. You choose a member indeed; but when you have chosen him, he is not member of Bristol, but he is a member of parliament. If the local constituent should have an interest, or should form an hasty opinion, evidently opposite to the real good of the rest of the community, the member for that place ought to be as far, as any other, from any endeavour to give it effect. ${ }^{84}$

Burke imagined representatives as trustees, not as delegates. ${ }^{85}$ In his view, representatives were charged with following their own understanding of the best course of conduct to pursue for the polity as a whole, which on particular issues may differ from the wishes of the citizens who voted for them (and may at least partially reflect the understanding of those who did not). "It was necessary to be sensitive to local opinion, and equally to the sentiments of the nation at large," the prominent Burke biographer Richard Bourke writes of Burke's views ${ }^{86}$ But "the highest role of a representative was to deliberate on the national interest, and for this they would have to

${ }^{79}$ Edmund Burke, Speech to the Electors of Bristol (Nov. 3, 1774), reprinted in 1 The Founders' CONSTiTUtion, Ch. 13, Doc. 7 (1987), http://press-pubs.uchicago.edu/founders/documents/v1ch13s7.html.

${ }^{80}$ For discussions, see Richard Bourke, EMPIRE \& REVOlution: THE POLITICAL LIFE OF EDMUND BuRKE 373-90 (2015), and James Conniff, Burke, Bristol, and the Concept of Representation, 30 W. PoL. Q. 329, 332-41 (1977).

${ }^{81}$ BOURKe, supra note 80 , at 381.

${ }^{82}$ Id.; Conniff, supra note 80, at 332-33.

${ }^{83}$ BOURKe, supra note 80 , at 381 .

${ }^{84}$ BURKE, supra note 79.

${ }^{85}$ Conniff, supra note 80 , at 336.

${ }^{86}$ BOURKE, supra note 80 , at 384 . 
subordinate particular interests to the common good, and interpret popular feeling in accordance with their own prudence." 87

In the same speech, Burke declared that "government and legislation are matters of reason and judgment, and not of inclination," and he rhetorically asked "what sort of reason is that, in which the determination precedes the discussion; in which one set of men deliberate, and another decide; and where those who form the conclusion are perhaps three hundred miles distant from those who hear the arguments?" 88 Another student of Burke's thought, James Conniff, accordingly underscores that Burke viewed governance as not simply a matter of "will" but of "judgment" about "what is best to be done," which requires deliberation among representatives, who are characteristically more informed about public affairs than their constituents. $^{89}$

At the same time, Burke believed that representatives must defend their votes and other conduct in office. ${ }^{90} \mathrm{He}$ also believed that they must ultimately submit to the judgment of their constituents - as Burke himself did when he withdrew from the 1780 election upon realizing that he had alienated too many of his constituents to be returned to Parliament. ${ }^{91}$ (He had disagreed with them on, among other things, the government's policy in America. ${ }^{92}$ ) But Burke's eventual rejection by his constituents did not alter his conception of the theoretical relationship between representatives and voters that he had expressed six years earlier. ${ }^{93}$

Americans living today need not accept a full-fledged (and frankly elitist) conception of elected representatives as trustees, let alone Burke's views on virtual representation, ${ }^{94}$ to see the

${ }^{87} I d$.

${ }^{88}$ BURKE, supra note 79.

${ }^{89}$ Conniff, supra note 80 , at 333. See BURKE, supra note 79:

It is [a representative's] duty to sacrifice his repose, his pleasures, his satisfactions, to theirs; and above all, ever, and in all cases, to prefer their interest to his own. But his unbiassed opinion, his mature judgment, his enlightened conscience, he ought not to sacrifice to you, to any man, or to any set of men living. These he does not derive from your pleasure; no, nor from the law and the constitution. They are a trust from Providence, for the abuse of which he is deeply answerable. Your representative owes you, not his industry only, but his judgment; and he betrays, instead of serving you, if he sacrifices it to your opinion.

${ }^{90}$ BOURKE, supra note 80 , at 387 .

${ }^{91} I d$. at $386-89$.

${ }^{92}$ Id. at 386; Conniff, supra note 80, at 332.

${ }^{93}$ BOURKE, supra note 80 , at 389; Conniff, supra note 80 , at 334. In conceding on September 9, 1780, Burke told his constituents, "I received your Trust in the face of day, in the face of day, I accept your dismission." Edmund Burke, Speech on the Hustings at Bristol (Sept. 9, 1780), in III The Writings AND SpEeCheS Of EDMUND BURKE 667 (Paul Langford et al. eds., 1970).

${ }^{94}$ Finding value in Burke's conception of the role responsibilities of elected representatives does not commit one to the Crown's claims for virtual representation of the American colonists, see JACK P. GREENE, THE CONSTITUTIONAL ORIGins OF THE AMERICAN REVOlution 67-72 (2010), let alone to American men's claims for virtual representation of women, see Reva B. Siegel, She the People: The Nineteenth Amendment, Sex Equality, Federalism, and the Family, 115 HARV. L. REV. 947, 992-93 (2002). Arguments for virtual representation require justification for allowing only certain groups and not others to vote for representatives. How representatives execute 
value in having presidents and members of Congress who have partially internalized a Burkean point of view. A Burkean perspective helps illuminate why it is deeply problematic for a representative to regard constituents who did not vote for her as outside her circle of concern. And, in circumstances like the contemporary United States, in which geography has taken on a partisan dimension, a Burkean vantage point also helps explain why it is troubling for a representative to vote to shift costs from her district or state onto others. ${ }^{95}$

To be clear, this Article emphasizes themes that are most strongly associated with the trustee model of representation, as opposed to the delegate model, ${ }^{96}$ in the conviction that those themes are most absent (and needed) in contemporary American politics, most directly connected to the American ideal of democracy as collective self-governance, and most reflective of the values animating constitutional provisions that set fixed terms (of two-to-six years) for federal elected officials and do not permit instructions to, or recall of, those officials. ${ }^{97}$ The Article does not, however, mean to reject the insights offered by the other traditions. ${ }^{98}$ For example, the delegate model of representation, which characteristically instructs a representative to follow the wishes of her constituents, straightforwardly explains why it is wrong for the representative to betray her own supporters by sacrificing their concerns to those of her wealthy donors or herself. The distinctions among the traditions are easily overstated, and nuanced theorists who write in one tradition also emphasize themes from the others. ${ }^{99}$ Americans reasonably make contradictory demands of representatives. Moreover, Hanna Pitkin famously emphasized the paradoxical nature of the concept of representation; urged theorists to stop trying to resolve the paradox; and suggested that representatives may think of themselves as both trustees and delegates. ${ }^{100}$

their responsibilities once in office is not the same question, even if it is also not an entirely unrelated question. For a discussion of the ways in which Burke's own support for virtual representation was qualified (for example, he did not think it was possible in the case of America), see Conniff, supra note 80, at 338-39.

95 To see the potential difference between taking seriously the interests of one's constituents as a whole and taking seriously the interests of the nation as a whole, consider a recent example. A Republican from a low-tax "red" state whose constituents voted for him by a healthy margin over his opponent might be acting in the interests of not only the voters who voted for him, but also in the interests of the voters in his district who voted for the Democrat, by supporting the recent federal tax bill to the extent it shifts the burden of taxation from "red" states to "blue" states (by eliminating or greatly reducing the deductibility of state and local taxes). The Republican from the low-tax state is taking seriously the interests of his Democratic constituents, but he is not obviously considering the interests of both Republican and Democratic constituents in other states.

96 The debate over "trustee" versus "delegate" models of representation is related to the debate over liberal versus republican theories of representation. For a cogent discussion of the latter debate, as well as of critical theories that reject both the liberal and republican traditions, see William N. EsKRIDGE, JR., PHILIP P. FRICKEY \& ELIZABETH GARRETT, LEGISLATION AND STATUTORY INTERPRETATION 19-22 (2nd ed. 2006).

${ }^{97}$ Critics of the original Constitution pushed unsuccessfully for the addition of a right to instruct federal

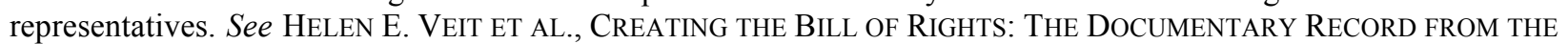
FIRST FEDERAL CONGRESS 151-77 (1991).

\footnotetext{
${ }^{98}$ See, e.g., infra notes 183-186 and accompanying text (emphasizing a concern of critical theorists).

99 ESKRIDGE ET AL., supra note 96, at 20-21.

${ }^{100}$ See PITKIN, supra note 68, at 154-55, 165-67.
} 
Granting all that, one can still be forgiven for asking skeptical questions about what it can mean for an often-divided people to still constitute "one nation, with one interest, that of the whole." ${ }^{\prime 101}$ But just as a crude legal realism can be self-fulfilling when legal actors reason from a realist point of view, the spirit of Burke's perspective can be conducive to the development of a constitutional role morality that prompts elected officials to see beyond their own political base. Of course, the caution that "realism yields realism" risks provoking the response that "blind faith yields suckers." Such a response is especially tempting at moments of exasperation after learning about the latest political outrage committed by the "other side." The challenge may be to avoid cynicism on the one hand and naiveté on the other - to develop a more inspiring account of American politics that realism can nonetheless potentially accept as true at some future time. ${ }^{102}$

On the American side of the Atlantic, James Madison articulated a Burkean perspective, at least in part, in his public advocacy in support of the Constitution's ratification. ${ }^{103}$ Madison decried both majority and minority faction in Federalist 10, and he emphasized the importance of "refin[ing] and enlarge[ing] the public views, by passing them through the medium of a chosen body of citizens, whose wisdom may best discern the true interest of their country, and whose patriotism and love of justice, will be least likely to sacrifice it to temporary or partial considerations." "Under such a regulation," he continued, "it may well happen that the public voice, pronounced by the representatives of the people, will be more consonant to the public good than if pronounced by the people themselves, convened for the purpose." Madison's representatives, like Burke's, would ideally pursue the "public good" instead of the narrow interests of their constituents ${ }^{105}$ - or themselves. ${ }^{106}$ "As there is a degree of depravity in mankind which requires a certain degree of circumspection and distrust," Madison wrote in Federalist 55, "so there are other qualities in human nature which justify a certain portion of esteem and confidence. Republican government presupposes the existence of these qualities in a higher degree than any other form." 107

${ }^{101}$ Burke, supra note 79.

102 Cf. Benjamin N. Cardozo, The Nature of the Judicial Process 127 (1921) ("We must seek a conception of law which realism can accept as true.").

103 For discussion of the similarities and differences between Burke's and Madison's views on representation, see PITKIN, supra note 68, at 190-92.

104 The Federalist No. 10, at 82 (James Madison) (Clinton Rossiter ed., 1961).

${ }^{105} I d$. Madison thought that larger election districts would help produce better representatives than would smaller election districts. Id. at 82-83.

106 Drawing from (among many other things) Madison's views about the obligations of elected representatives, Theodore Rave argues that political representatives, like corporate agents, should be treated as fiduciaries and so subject to a duty of loyalty, which they breach when they manipulate election laws to their own advantage. See D. Theodore Rave, Politicians as Fiduciaries, 126 HARV. L. REV. 671, 710-11 (2013). Rave's project is distinct from this one in that he focuses on judicial enforcement of legal obligations that representative agents owe to their diffuse principals. Nonetheless, conceiving of representatives as fiduciary agents is in the spirit of this Article, which asks into the political obligations that elected officials should have to a set of principals that includes not only their own supporters, but also the political opposition, the nation as a whole, and the governmental institutions in which they serve.

107 The Federalist No. 55, at 346 (James Madison) (Clinton Rossiter ed., 1961). 
To be sure, Madison is typically viewed as having been a proponent of the delegate model of representation, ${ }^{108}$ Because he believed that "[e]nlightened statesmen will not always be at the helm," his "principa[1]" solution to the problem of majority faction was structural, not Burkean. ${ }^{109} \mathrm{He}$ endorsed extending the sphere of republican government to encompass greater social heterogeneity, thereby making majority factions less likely to form and, if they do form, less likely to act in concert effectively. ${ }^{110}$ Madison was thus suggesting that the contents and interactions of citizen preferences in the national legislature of the extended republic would help ameliorate the problems associated with poor representatives. It is important to note, however, that Madison emphasized both extending the sphere and securing high-quality representatives. "In the 1780s," Gordon Wood writes, "James Madison had his doubts about this moral capacity of the people stretched to the limit, but even he admitted that ordinary people had to have sufficient 'virtue and intelligence to select men of virtue and wisdom' or 'no theoretical checks, no form of government, can render us secure.",111

Notably, Madison's objective in extending the sphere was to force greater consensus in political decision-making. "In the extended republic of the United States, and among the great variety of interests, parties and sects which it embraces," Madison wrote at the end of Federalist 51, "a coalition of a majority of the whole society could seldom take place on any other principles than those of justice and the general good."112 Madison's two approaches are thus potentially related in that public-spirited representatives may be necessary to prevent the extended sphere from causing negotiation and coalition-building in Congress to fail routinely. ${ }^{113}$ That risk, whose associated costs have increased substantially over time as Americans have come to expect more of the federal government than they did in Madison's day, is discussed in the next sub-Part.

${ }^{108}$ Madison defined representative government as involving "the delegation of the government . . . to a small number of citizens elected by the rest." THE FEDERALIST No. 10, at 82 (James Madison) (Clinton Rossiter ed., 1961). See Dovi, supra note 68 (contrasting Madison's views on representation with Burke's).

${ }^{109}$ See Larry Kramer, Madison's Audience, 112 HARV. L. REV. 611, 658 n.206 (1999) (noting the debate among historians regarding whether Madison placed greater emphasis on improving the quality of representatives or extending the sphere, and opining that "[i]t is a strange debate, inasmuch as Madison's own words leave little room for doubt that he viewed the effect of size in diluting faction as more important").

${ }^{110}$ The Federalist No. 10, at 83 (James Madison) (Clinton Rossiter ed., 1961) ("Extend the sphere, and you take in a greater variety of parties and interests; you make it less probable that a majority of the whole will have a common motive to invade the rights of other citizens; or if such a common motive exists, it will be more difficult for all who feel it to discover their own strength, and to act in unison with each other.").

${ }^{111}$ Gordon S. WOOD, EMPIRE OF LibERTY: A History OF THE EARLy RePUBLIC, 1789-1815, at 9 (2009); see RALPH KetChAM, JAMES MADISON: A BIOGRAPHY 300 (1990) ("Madison insisted repeatedly that the future of republican government was hopeless without some confidence in human virtue ....").

112 The Federalist No. 51, at 325 (James Madison) (Clinton Rossiter ed., 1961).

${ }^{113}$ Madison posited that the diversity present in the extended republic would be reflected and managed in Congress. See, e.g., Samuel Kernell, "The True Principles of Republican Government": Reassessing James Madison's Political Science, in JAMEs MAdison: THE THEORY AND PRACTICE OF REPUBlican Government 92, 92 (Samuel Kernell ed., 2003) ("In Number 10 his solution takes the form of an extended republic containing numerous, diverse factions whose representatives reconcile their competing interests in a well designed, deliberative national legislature.”). 
The presidency of George Washington was practically obsessed with ideas about proper behavior by government officials. Washington was mindful that Article II did not define "[t]he executive Power" ${ }^{114}$ with anything approaching the precision with which Articles I and III defined the federal legislative and judicial powers, respectively. He was also aware that the ways in which he chose to execute his responsibilities would likely set precedents for future presidents. ${ }^{115}$ Washington made fateful decisions with respect to recognizing and derecognizing foreign governments, communicating (including in secret) with foreign governments and negotiating treaties without the Senate's prior knowledge, seeking Senatorial consent but not advice in the treaty-making process, making the ultimate decision (after Senate consent) to ratify treaties himself in the name of the nation, and insisting that cabinet members served at his pleasure and so could be removed without cause and without Senate consent. ${ }^{116}$ Although Washington mostly (and appropriately) defended the authority of the presidency in those episodes, he also insisted upon obtaining congressional authorization before engaging in any non-defensive use of the military (most notably against Indian tribes). ${ }^{117}$

Most significant for present purposes is an observation by Akhil Amar: "Washington, by temperament and philosophy, was a consensus-seeker." 118 Just as "[w]ar councils had served him well when he was a battlefield general," so "in his vision of public service, patriotic officials of all stripes should ideally converge on nonpartisan solutions when presented with the same facts." 119 As a result, Washington "sought advice from his departmental heads even on topics beyond the strict boundaries of their respective departmental assignments, and later presidents followed suit." ${ }^{120}$ Relatedly, Washington put rivals (such as Hamilton and Jefferson) in his cabinet. And during his first term, he started a presidential tradition of visiting the states in order to interact with Americans, including long trips up through New England and then down through the South-all thirteen states - in an effort to foster national unity, which he understood the nation would require if it were going to endure. ${ }^{121}$

${ }^{114}$ U.S. CONST. art. II, $\S 1$, cl. 1.

${ }^{115}$ Members of the first Congress were also aware of the potential precedent-setting implications of their proceedings. Madison, for example, told his colleagues in the first Congress that their own decision regarding the power of the president to remove executive branch officials unilaterally "will become the permanent exposition of the Constitution.” 1 Annals of Cong. 514 (1789). For a discussion, see Curtis A. Bradley \& Neil S. Siegel, After Recess: Historical Practice, Textual Ambiguity, and Constitutional Adverse Possession, 2014 SuP. CT. Rev. 1, 2829 (2015). For a recent, popular history of the first Congress, see generally FERGUS M. BORDEWICH, THE FIRST

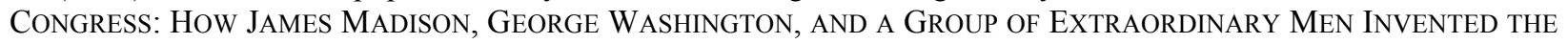
GOVERNMENT (2016).

\footnotetext{
${ }^{116}$ For a discussion, see AMAR, AMERICA's UNWRITTEN CONSTITUTION, supra note 14, at 307-32.

117 See Curtis A. Bradley \& JaCK L. Goldsmith, Foreign Relations LAw: CASES AND Materials 637
} (6th ed. 2017) (discussing President's Washington's views on the permissibility of non-defensive uses of military force by the president).

118 AMAR, AMERICA's UNWRITTEN CONSTITUTION, supra note 14, at 326.

${ }^{119} \mathrm{Id}$.

${ }^{120} \mathrm{Id}$. (2016).

${ }^{121}$ See generally T.H. Breen, George Washington's Journey: The President Forges a New Nation 
In addition, Washington's patriotic insistence on renouncing power-first after successful military command, and then after serving for eight years as president - reflected his conviction that continued power was improper and dangerous, even if not unlawful, and so not in the best interests of the nation. Washington played the initial, pivotal role in establishing the constitutional convention against presidents serving more than two terms, which was legally permissible prior to the adoption of the Twenty-Second Amendment in $1951 .{ }^{122}$ Washington stepped down, and it was generally thought thereafter that it would be improper to deviate from his example. Ratification of the 22nd Amendment, which legally limited presidents to two terms, likely signified that President Franklin Delano Roosevelt (FDR) had contravened the convention (or, perhaps, had availed himself of an emergency exception to it), ${ }^{123}$ not that the convention had never existed. ${ }^{124}$

Even as much of a majoritarian and a partisan as Thomas Jefferson was moved to voice an inclusive conception of American governance in his First Inaugural Address. (Presidents often speak that way after a bruising election campaign, and it may be unduly cynical to dismiss their addresses simply as cheap talk, as opposed to efforts to appeal to their and our better selves.) Jefferson spoke after a deeply divisive contest between the incumbent Federalist Party and Jefferson's own Democratic Republican Party that was ultimately settled in the House of Representatives. "[T]hough the will of the majority is in all cases to prevail," he said, "that will, to be rightful, must be reasonable; . . . the minority possess their equal rights, which equal laws must protect, and to violate would be oppression." 125 Continuing, he famously declared that "[w]e are all republicans: we are all federalists." ${ }^{126}$ To Jefferson, such sentiments were part of "the creed of our political faith; the text of civic instruction, the touchstone by which to try the services of those we trust." ${ }^{\text {.127 }}$ He added that "should we wander from them in moments of error or of alarm, let us hasten to retrace our steps, and to regain the road which alone leads to peace, liberty and safety." 128

For Burke, Madison, Washington, Jefferson, and a host of eminent academic theorists, democratic politics is not persuasively viewed as simply licensing the public indulgence of one's ideological appetites or the exercise of one's will. Democracy is also a principled realm, one that both enables and constrains. In such a realm, having the legal power to accomplish an objective does not make it appropriate to do so. As Eric Posner recently put the point simply but

${ }^{122}$ For a discussion of constitutional conventions, see infra notes 167-173 and accompanying text.

${ }^{123}$ See Joseph Jaconelli, The Nature of Constitutional Convention, 19 LEgAL STUD. 24, 33 (1999) (suggesting that the constitutional convention could be read as subject to an exception in circumstances of emergency, so that FDR could be understood as having acted within the terms of the convention).

${ }^{124}$ For a discussion, see Bradley \& Siegel, supra note 46, at 267-68.

${ }^{125}$ Thomas Jefferson, First Inaugural Address (Apr. 30, 1801), in 33 THE PAPERS OF THOMAS JEFFERson, 148-52 (2006), https://jeffersonpapers.princeton.edu/selected-documents/first-inaugural-address-0.

${ }^{126} I d$.

${ }^{127} I d$.

${ }^{128} I d$. 
powerfully, "[t]he president's authority rests on trust and discretion, not on triumph of the will." $" 129$

Governance that is narrowly partisan can strain the relationships of trust that are necessary to make collective self-governance realizable to an appreciable extent in the United States. A constitutional role morality that tasks elected officials with trying in good faith to achieve some level of inclusivity and bipartisan support reinforces those relationships of trust. Elected officials may often fail to achieve such support, and sometimes they should fail: just as bare democratic majorities can be right or wrong about profoundly important matters, so can supermajorities. But it may be worth keeping in mind that Madison was not thinking as a partisan when he supported adding rights provisions to the original Constitution so as to "render it as acceptable to the whole people of the United States, as it has been found acceptable to a majority of them." 130 Likewise, Lincoln did not have narrow partisan majorities in mind when he poignantly resolved that the American nation "shall have a new birth of freedom" and that "government of the people, by the people, for the people, shall not perish from the earth." "131 That much is evident from his own efforts at national reconciliation-without compromising over slavery-before he was assassinated. ${ }^{132}$

\section{B. A Well-Functioning Federal Government}

In addition to the American conception of democracy as collective self-governance, which other political communities may share, another foundation upon which to rest a constitutional role morality for elected officials is more distinctly American. The United States Constitution brought into being a robust system of separation of powers and checks and balances. The Framers fashioned such a horizontal constitutional structure without anticipating political parties, let alone the ideological parties in existence today but absent throughout most of the twentieth century. That regime of separation of powers, which is often characterized by the

129 Eric Posner, Judges v. Trump: Be Careful What You Wish For, N.Y TIMES (Feb. 15, 2017), https://www.nytimes.com/2017/02/15/opinion/judges-v-trump-be-careful-what-you-wish-for.html?_r=1.

${ }^{130} 1$ ANNALS OF CONG. 448-49 (1789).

131 Abraham Lincoln, The Gettysburg Address, ABRAHAM LinCOLN OnLINE (Nov. 19, 1863), http://www.abrahamlincolnonline.org/lincoln/speeches/gettysburg.htm.

${ }^{132}$ Senate Majority Leader Mitch McConnell's firm rejection of President Trump's idea of eliminating the filibuster as to legislation can potentially be understood as resting in part on a normative and anti-sheer-majoritarian conception of the role of the Senate. See Aaron Blake, Mitch McConnell Just Rebuked Trump's Suggestion to Nuke the Filibuster. Here's Why., WASH. POST (May 2, 2017), https://www.washingtonpost.com/news/thefix/wp/2017/05/02/3-reasons-the-gop-wont-nuke-the-filibuster-and-give-trump-more-

power/?utm_term $=.374 \mathrm{cdb0e} 4 \mathrm{fa} 5$. On the other hand, a less charitable interpretation is possible. See, e.g., Fred Barnes, Mitch McConnell Goes to the Mattress for Trump's Judicial Nominees, THE WeEKLY STANDARD (Oct. 11, 2017), http:/www.weeklystandard.com/mitch-mcconnell-goes-to-the-mattresses-for-trumps-judicialnominees/article/2010022 (noting the various actions that Leader McConnell has taken to prevent Senate Democrats from impeding the confirmation of President Trump's judicial nominees, including the elimination of "blue slips," which in the past had allowed senators to bar a nominee from their state by refusing to return their slip to the Senate Judicial Committee, thereby preventing a hearing and confirmation). 
separation of parties in control of different parts of the government, ${ }^{133}$ creates ample opportunities for one political party, or a part of one party, to thwart potential action by the federal government. Moreover, because the minority party in the Senate is empowered to filibuster most legislation, the problem of potential paralysis endures in circumstances of unified government. As a result, troubling questions arise regarding how the federal government is to execute its basic responsibilities of filling executive and judicial offices, solving problems that the states are not well-situated to address on their own (characteristically, multi-state collective action problems), ${ }^{134}$ and safeguarding rights through the passage and updating of civil rights legislation (which several constitutional provisions authorize Congress to do). ${ }^{135}$ The separation and interrelation of powers are supposed to cabin and qualify the exercise of the substantial set of powers that the Constitution vests in the federal government. The separation is not supposed to largely negate or neuter those powers.

Commentators who reject that understanding of the limited role of the separation of powers in the constitutional scheme will likely reject the analysis that follows in this sub-Part. Unfortunately, an attempt to fully defend the structural vision emphasized here would take this Article too far afield. For present purposes, two points will have to suffice. First, the Framers of 1787 gathered in Philadelphia to substantially enhance federal power, not to restrict it. ${ }^{136}$ Given the heated rhetoric about a federal leviathan that one often encounters, it bears emphasizing that the perceived problem in the $1780 \mathrm{~s}$ was that the national government under the Articles of Confederation was way too weak, not that it was so strong that a complex institutional architecture was needed to restrain it. ${ }^{137}$ Second, and fast-forwarding to the present, most Americans living today look to the federal government to actually exercise its powers in a variety of ways, not to be consistently hamstrung in its ability to do so. There comes a point at which the "checks and balances" theory of the horizontal constitutional structure malfunctions; rather than acting to discourage ill-considered or excessive federal action, all the veto gates produce hopeless gridlock and obstructionism.

One obvious response is to invoke the vertical constitutional structure - that is, federalism. On that view, it is a good thing (or at least not a bad thing) if the federal government

${ }^{133}$ See generally Daryl J. Levinson \& Richard H. Pildes, Separation of Parties, Not Powers, 119 HARV. L. REV. 2311 (2006).

${ }^{134}$ For work developing and applying the theory of collective action federalism, see generally Robert D. Cooter \& Neil S. Siegel, Collective Action Federalism: A General Theory of Article I, Section 8, 63 STAN. L. Rev. 115 (2010) [hereinafter Cooter \& Siegel, Collective Action Federalism]; Neil S. Siegel, Free Riding on Benevolence: Collective Action Federalism and the Minimum Coverage Provision, 75 LAW \& ConTEMP. ProBS., 29 (2012) (no. 3) [hereinafter Siegel, Free Riding on Benevolence]; Neil S. Siegel, Collective Action Federalism and Its Discontents, 91 TEX. L. REV. 1937 (2013) [hereinafter Siegel, Collective Action Federalism and Its Discontents].

${ }^{135}$ The structural logic of the federal government's role in protecting civil rights is distinct from the logic of collective action. See Siegel, Collective Action Federalism and Its Discontents, supra note 134, at 1948 ("'[T]he enforcement clauses [of the Civil War Amendments] give Congress authority to regulate the internal policy choices of state governments concerning certain subject matters regardless of collective action problems facing the states.") (footnotes omitted).

${ }^{136}$ See, e.g., Cooter \& Siegel, Collective Action Federalism, supra note 134, at 117, 121-24.

${ }^{137}$ For a recent, detailed substantiation of that claim, see generally GeORGE WILLIAM VAN CLEVE, We

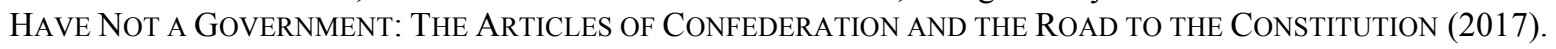


is incapable of taking effective action; the states can often act effectively, and federal inaction leaves the states more room to maneuver. To understand why that position is ultimately unpersuasive, it is important to recall the basic insight of collective action federalism. ${ }^{138}$ There are many problems in today's modern, integrated economy and society whose nature and scope disrespect state borders, so that the states actually need the federal government to be able to step in. Examples include military defense, anti-terrorism efforts, interstate markets, interstate infrastructure, and environmental protection. Where collective action by states is required in order for substantial progress to be made, having a strong, effective federal government promotes rather than undermines state autonomy. Accordingly, if one examines the entire American constitutional structure - not just the horizontal separation and interrelation of powers at the federal level, but also the vertical separation of powers between the federal government and the states - the most compelling conclusion is that all Americans, as well as state governments themselves, are better served as a general matter by a federal government that can act, and act effectively. ${ }^{139}$

There is another reason why the separation of powers and parties may at first glance seem like only a feature and never a bug. If (as the previous sub-Part argued) governmental action that is narrowly partisan can be a problem from the standpoint of collective self-governance, then part of the solution is to impose consensus-forcing devices, and veto gates can serve that function. No doubt, there is truth in that reasoning: a close relationship exists between, say, the filibuster as to appointments or legislation and the facilitation of collective self-rule. The difficulty is that facilitating collective self-governance is not the only responsibility of the federal government. As noted, the political branches are also charged with accomplishing various tasks associated with governance, from appointing officials to enacting legislation. And veto gates can result in Congress accomplishing little, which has arguably been the case at the federal level too often in recent years. For example, whatever one's preferred solution to the problem of more than eleven million undocumented people living to a significant extent in the shadows in the United States, the federal government should also be addressing the issue through new legislation, not just through unilateral action by the president (whether Obama or Trump). ${ }^{140}$

\footnotetext{
${ }^{138}$ For work on the theory of collective action federalism, see supra note 134.

${ }^{139}$ Disaggregating the federal government, there may be an additional structural reason why, from the perspective of the states, a gridlocked Congress is cause for concern. Power flows to where it can be exercised, and in the United States it flows from Congress not just to the states, but also to the President. The latter power flow arguably undermines the regulatory autonomy of the states because it circumvents the political safeguards of federalism; the interests of the states are presumably better represented in Congress than in the Executive Branch. For seminal contributions to the literature on the political safeguards, see generally JESSE CHOPER, JUDICIAL REVIEW And the National Political Process 171-259 (1980); Larry Kramer, Understanding Federalism, 47 VAND. L. REV. 1485 (1994); Andrzej Rapaczynski, From Sovereignty to Process: The Jurisprudence of Federalism After Garcia, 1985 Sup. CT. ReV. 341; and Herbert Wechsler, The Political Safeguards of Federalism: The Role of the States in the Composition and Selection of the National Government, 54 CoLUM. L. REV. 543 (1954).

${ }^{140}$ That is not to say a president should never act in the absence of congressional action. Whether to act depends on a contextual judgment about legal authority, role morality, and harms being visited upon human beings in the status quo. There is, for example, room to argue that it would be irresponsible for the president to do nothing with respect to a particular pressing problem (such as climate change) after it becomes clear that Congress will not act for the duration of his or her presidency.
} 
To be sure, a number of heated political disagreements in America today are in part precisely about how much action the federal government should be taking. As noted, however, it also seems true that Americans of most ideological stripes want the federal government to be able to act effectively, even if they sometimes disagree about the spheres or directions in which such effective action should take place. ${ }^{141}$ (Demands for a robust federal response to the latest natural disaster continuously bring that point home.) And the federal government cannot function effectively if presidents or parties in control of Congress push to the legal limits their powers to, for example, veto legislation, nominate aggressive partisans, decline to nominate people to fill key positions, repeatedly filibuster executive or judicial branch nominees or legislation, and deny confirmation hearings or votes (or not consider nominees at all).

Consider again, for example, the Senate's handling of judicial nominations in recent years. ${ }^{142}$ Because the Supreme Court is not like other courts, it is a serious problem if we have in fact reached the point at which Supreme Court vacancies will go unfilled unless the same political party controls the White House and the Senate. The Supreme Court plays a unique role in ensuring uniformity on important questions of federal law, and an even number of Justices on a closely divided Court impairs its ability to execute that responsibility. The Court ends up granting fewer cases, splitting 4-4 on some of the cases it does agree to hear (thereby not establishing a precedent), and deciding some cases very narrowly (thereby offering little guidance) in order to avoid such splits. ${ }^{143}$ Moreover, judges from other courts cannot sit by designation in order to break ties, nor could visiting judges provide the kind of guidance and stability that the legal system often requires.

That example illustrates the potential tension between the pursuit of collective selfgovernance and the pursuit of effective self-governance - of collective action. The question the example raises is whether there are, or can be developed, normative constraints on elected officials over and above strictly legal limits that can encourage officials to participate in the political process with some self-restraint, and so refrain from pushing their powers to their respective maxima. As the English Whig and Liberal politician (and future prime minister) Lord John Russell wrote to Poulett Thomson in 1839 while the latter was Governor General of Canada, "[e]very political constitution in which different bodies share the supreme power is only enabled to exist by the forbearance of those among whom this power is distributed. . . Each must exercise a wise moderation." ${ }^{144}$ Representatives disserve everyone, including Americans who did vote for them, when they undermine the proper functioning of the constitutional system.

${ }^{141}$ See generally, e.g., Neil S. Siegel, None of the Law but One, 62 DrAKE L. REV. 1055 (2014) (collecting numerous examples of ways in which today's congressional Republicans, like congressional Democrats, possess and seek to leverage a broad view of the constitutional scope of federal power).

142 See supra notes 23-25 and accompanying text (discussing this issue).

${ }^{143}$ For a discussion, see Neil S. Siegel, The Harm in the GOP's Pseudo-Principled Supreme Court Stance, THE HiLl (Apr. 15, 2016), http://thehill.com/blogs/pundits-blog/the-judiciary/276462-the-harms-in-being-pseudoprincipled-about-the-supreme-court.

144 Letter of Lord John Russell to Poulett Thomson (October 14, 1839), available at http://www.constitution.org/sech/sech_133.txt. This quote appears in WOODROW WILSON, CONGRESSIONAL GOVERNMENT 165 (1885). I thank Peter Shane for those references. See also Edmund Burke, An Appeal from the New to the Old Whigs, in 4 THE WORKS OF THE Right HonORABle EdMUnd Burke 208 (1889) ("[I]n the British constitution, there is a perpetual treaty and compromise going on."). 
Relevant in this regard is the political science literature suggesting that today's elected officials are disserving their constituents (including the people who voted for them) by pursuing policies that are more extreme than what their constituents would want. ${ }^{145}$

Thomas Jefferson, as Secretary of State, insisted that there were normative constraints on the political discretion of elected officials. President Washington asked him for a formal legal opinion on the question of whether the Senate had the right to negative the grade of persons appointed by the president to fill foreign missions. As my colleague H. Jefferson Powell explains, "Eighteenth century international law and etiquette recognized an elaborate hierarchy of diplomats." 146 The "grade" was the place in the hierarchy that "a country accorded its representative(s) to another state," and it "was itself a substantive act in the conduct of foreign relations." 147 After analyzing the question presented and concluding that the Senate lacked such power, Jefferson considered the counterargument "that the Senate may, by continual negatives on the person, do what amounts to a negative on the grade; and so indirectly defeat this right of the President." "148 Jefferson's answer was that "this would be a breach of trust, an abuse of the power confided to the Senate, of which that body cannot be supposed capable." 149 "If the Constitution had meant to give the Senate a negative on the grade or destination, as well as the person," Jefferson reasoned, "it would have said so in direct terms, and not left it to be effected by a sidewind." 150 He concluded: "It could never mean to give them the use of one power thro the abuse of another." ${ }^{151}$ Particularly in current, polarized times, it is not difficult to dismiss as hopelessly naïve Jefferson's invocation "a breach of trust, an abuse of power confided to the Senate." But it may be especially important in such times to resist reaching for the cynical acid.

A constitutional role morality for elected officials can be based in part upon the normative desirability of keeping partisanship within reasonable bounds so that the federal government can function more effectively and with greater stability-so that there is more bipartisan action by the federal government, as opposed to opposition-forced inaction or narrowly partisan action (often accompanied by a disreputable policymaking process) in order to overcome the opposition. A role morality for elected officials, while not in the Constitution, is deeply connected to the Constitution because law alone is not enough to sustain the American constitutional project. Disregarding the role expectations that pertain to elective office is not simply bad politics or policy, but constitutes a deviation from norms of good institutional citizenship that help the constitutional system endure. Such a suggestion may seem naïve, just as Jefferson's assessment of the question posed to him by President Washington may seem naïve.

${ }^{145}$ See, e.g., Jeffrey R. Lax \& Justin H. Phillips, The Democratic Deficit in the States, 56 AM. J. PoL. SCI. 148, 149 (2011) (finding, inter alia, that "state policy is far more polarized than public preferences").

${ }^{146}$ H. Jefferson Powell, The Law of the United States Constitution: Cases and Materials 74 (2017) (unpublished teaching materials) (on file with author).

${ }^{147} \mathrm{Id}$.

148 Thomas Jefferson, Opinion on the Powers of the Senate Respecting Diplomatic Appointments (Apr. 24, 1790), in 16 The Papers of Thomas JefFerson 378-82 (Julian P. Boyd ed., Princeton Univ. Press 1961).

${ }^{149} \mathrm{Id}$.

${ }^{150} \mathrm{Id}$.

${ }^{151} I d$. 
But it is also possible that many contemporary elected officials have lost their way and should be encouraged to find their way back. The same should be said of the donors, party officials, advocacy groups, media outlets, and constituents who constitute the environment in which elected officials must function.

\section{The Contents of Constitutional Role Morality}

What should a role morality for elected officials of the federal government look like? How does it differ from governmental paralysis? This Part fleshes out those questions and offers preliminary answers. The first sub-Part defines the problem and explains why it would be advisable to temper expectations regarding the articulation of solutions. The second sub-Part offers potential candidates for inclusion in a constitutional role morality.

In order to make some progress on what is a profoundly difficult set of issues, this Partlike the Article more generally-will engage in abstraction by discussing federal elected officials as a general class of actors, at least for the most part. In reality, however, presidents may be differently situated from members of Congress in certain respects; for example, presidents are the leaders of their political party. Similar observations could be made of judges; for example, the role expectations of Supreme Court Justices may differ in significant ways from those of lower federal court judges. ${ }^{152}$ Yet it is still commonplace and useful for certain purposes to talk of judicial role morality in general. Because the question of whether a role morality applies to presidents and members of Congress at all is so under-explored among constitutional law scholars in the United States, it seems appropriate to lump federal elected officials together at this preliminary stage. There will be time enough to split them apart. ${ }^{153}$

\section{A. The Problem}

Grounding role expectations for federal elected officials in (1) the normative ideal of democracy as collective self-governance and (2) a well-functioning federal government implies that electoral winners owe something both to their political opponents, to the nation as a whole, and to the institutions in which they serve. But what do they owe? It cannot be correct in principle that moderation and compromise are always the proper course of action. And if supermajority support were required before elected officials could act, too little worth doing by the federal government would be accomplished in a polarized society. To put the point hyperbolically (as it has been put to me), winning an election cannot mean that you never really win, and losing cannot mean that you never really lose. Elections do have significant consequences, and the winners are entitled to act like it.

${ }^{152}$ See, e.g., Siegel, supra note 60, at 1222-24 (discussing similarities and differences between the behavior and job responsibilities of Supreme Court Justices and lower federal court judges).

${ }^{153}$ Because this Article grounds constitutional role morality in specific purposes of the U.S. Constitution, it seems appropriate to focus on federal elected officials, and not elected officials more generally. 
And so, the problem of what elected officials owe their opponents, nation, and institutions defies easy solutions. Before sketching some potential answers, three observations seem warranted. First, the question of what role morality demands of judges is also quite challenging. Yet because of what has been perceived to be at stake, the difficulty of the task has not dissuaded generations of constitutional law scholars, and even judges themselves, from attending to the problem. The same posture seems appropriate in the case of elected officials.

Second, this Article has relatively modest expectations. It will have succeeded to the extent that readers are far enough along in considering its argument to be moved to ask what role expectations for politicians should look like. The dominant discourse in American constitutional law and politics, including in most of the law review literature, assumes or asserts that there are no principled restraints on elected officials other than legality.

Third, it is important to have modest expectations in considering potential answers to the question of what role restraints should look like. Again, it is a terribly difficult question, and it has yet to be much analyzed by academic constitutional lawyers in the United States. As in the cases of theories of morality, political theories of representation, professional ethics in applicable fields, and role morality in the judicial realm, answers are likely to be contestable and contested, ${ }^{154}$ and to illuminate the question not just by revealing truth but also by exemplifying error. The most that can probably be hoped for, at least at this point, is to offer perspectives and starting points for critical assessment and further inquiry.

\section{B. $\quad$ A Sketch of a Role Morality for Federal Elected Officials}

A vision of the constitutional role morality that attaches to federal elective office can be developed along at least three dimensions: the rhetorical, the procedural, and the substantive. Each is discussed below, in increasing order of difficulty. The distinction between procedure and substance, although a generally useful one, can be as challenging to draw on the edges in this context as in others. There is room for disagreement about the placement of certain considerations articulated below in one category or another. ${ }^{155}$

One of the first obligations that a constitutional role morality would likely impose on federal elected officials - the president above all others, but members of Congress as well - is to seek ways of reaching out rhetorically to Americans who voted against them. (In that regard, Jefferson's First Inaugural Address, discussed above, is a model. ${ }^{156}$ ) Moreover, a role morality would counsel officials to continue reaching out rhetorically throughout their time in office. Under no circumstances would a role morality advise elected officials to gratuitously alienate non-supporters by, for example, calling them names or mocking their identities or way

${ }^{154}$ See, e.g., supra Part I (discussing the enduring dissensus on questions of judicial role morality); infra notes 206 and accompanying text (same).

${ }^{155}$ For example, one could categorize "not taking everything one can get away with taking from a negotiation" (an idea discussed below) as substantive because it concerns outcomes and not deliberations, or one could categorize it as procedural because it does not depend upon evaluating the merits of specific policies.

${ }^{156}$ See supra notes 125-128 and accompanying text (discussing Jefferson's First Inaugural Address). 
of life. Presidential candidate Hillary Clinton likely fell short in this regard when she said at a fundraiser that "you could put half of Trump's supporters into what I call the basket of deplorables." 157

A qualification is immediately in order. The feeling and expression of political sympathy and inclusion, even as a theoretical matter, may be (and certainly is in fact) conditional rather than unconditional. Accordingly, the rhetorical reaching out suggested above would need to know some bounds. It should likely be limited to Americans whose commitments and conduct fall within a broad, but not limitless, range of reasonable disagreement. ${ }^{158}$ Although the bounds of reasonableness will be contestable and contested (especially given the degrees of polarization and ill will that characterize contemporary American politics), there are at least some consensus candidates for exclusion from the universe of rhetorical concern. White supremacists, neo-Nazis, and terrorists come immediately to mind.

Even qualifying the claim in the way described above, an obvious response is that such sympathetic talk amounts to mere gestures, mere matters of appearance. It is primarily about appearances, but that observation counts against the proposal only on a cynical premise of disingenuousness that is rejected by the whole project of developing a constitutional role morality. As Justice O'Connor wrote in a different context (namely, the intersection of race and electoral design), "appearances do matter." 159 Americans will put up with a good deal of disappointment if they feel that they matter-that they are being respected and heard by elected officials even if the answer is "no." 160 A role morality for elected officials in the United States should likely reflect the idea that those who govern have a duty to make all of us feel that we are within the political community for whose welfare they are concerned.

It is easy to underestimate the significance of rhetoric. The reason politicians use rhetoric is that it can shape people's perceptions and commitments. A strengthened rhetoric of inclusion and equal concern is likely to shape reality in positive directions. Consider, in that regard, the social value of driving overt racism (almost) out of the public sphere-and of resisting its reintroduction. The shift in recent decades away from anti-LGBTQ rhetoric in the public sphere is another example of the power of rhetoric to change social attitudes. ${ }^{161}$

Procedurally, several promising possibilities are worth considering for inclusion in the role expectations of elected officials. Informing those possibilities is the insight of dialogic theorists of democracy, discussed above, that a procedural approach is the most feasible way to

${ }^{157}$ See Amy Chozick, Hillary Clinton Calls Many Trump Backers "Deplorables," and G.O.P. Pounces, N.Y. Times (Sept. 10, 2016), https://www.nytimes.com/2016/09/11/us/politics/hillary-clinton-basket-ofdeplorables.html. For Secretary Clinton's explanation of her statement, see HiLlaRY RODHAM ClinTON, WHAT HAPPENED 413 (2017).

158 Cf. generally JOHN RAWLS, POLITiCal Liberalism (1993) (emphasizing the reasonable yet irreconcilable disagreements about basic questions of religion, morality, and philosophy that characterize modern, heterogeneous societies).

${ }^{159}$ Shaw v. Reno, 509 U.S. 630, 647 (1993).

${ }^{160}$ For a discussion, see, for example, Siegel, supra note 48, at 1023-24.

161 See infra notes 206-207 and accompanying text (emphasizing the positive consequences of disagreement and dialogue). 
reconcile democracy and diversity. ${ }^{162}$ A procedural approach may also be a promising way to reconcile the entitlement of electoral winners to act on their promises to supporters with the other potential responsibilities discussed immediately below.

First, moving beyond rhetorical outreach, elected officials should have a responsibility to take seriously the concerns of non-supporters, the best interests of the nation, and the long-term health of their institutions by considering each of them in good faith. There ought to be some obligation to balance one's partisan and electoral interests against the interests of political opponents, the nation as a whole, and the institution in which one serves. Of course, this does not mean that politicians should not pursue their partisan and electoral interests. For example, a president ought to have due regard for the future of the political party that he or she leads; the party constitutes the primary institutional means of continuing his or her policies after leaving office. The modest suggestion here is only that politicians should not exclusively consider partisan and electoral interests.

Second, electoral winners should, at least as a general matter, have a duty to consult with opposition leaders before making important decisions or taking significant actions. In addition to building trust and facilitating cooperation, consultation is an important way to ensure that one's beliefs about political issues are epistemically responsible, meaning that they are formed and maintained without being distorted by ideology, wishful thinking, framing effects, confirmation bias, etc. ${ }^{163}$ A failure to consult is part of what we have seen in the political branches in recent years in the area of judicial nominations. ${ }^{164}$ As a result, both collective self-governance and the effective functioning of the federal government have arguably suffered.

Third, electoral winners should have an obligation to deliberate in good faith with opposition leaders when considering whether to take important actions. This does not mean that electoral winners should not ultimately act on their agendas. It does mean, however, that they should ordinarily not act before first attempting to enlist the support of, and then negotiate with, the other side. That is a more demanding obligation than the aforementioned proposals to consider and consult.

Another qualification is warranted. The above proposals to "reach out," "take seriously," "consult," "deliberate," and keep doing so throughout one's term in office raise obvious concerns about opportunity cost and futility. Life is short, time in elective office is even shorter, and unless the reaching out is relatively casual, elected officials may not have enough time and energy to keep at it, especially with respect to the ideological fringes of each party in Congress. How much reaching out, to whom, and for how long are not questions that can be answered theoretically; they require exercise of the human faculty of judgment in particular situations as they arise. The most that can be said theoretically is that elected officials will need to trade off the rhetorical and procedural values described above with the vindication of other

${ }^{162}$ See supra notes 69-77 and accompanying text (discussing the process approach of a range of democratic theorists).

${ }^{163}$ On the morality of responsible political belief formation, see ERIC BEERBOHM, IN OUR NAME: THE ETHICS OF DEMOCRACY 1-24, 142-65 (2012).

${ }^{164}$ See supra notes 23-25 and accompanying text (discussing the Senate's handling of judicial nominations in recent times). 
important values, including those associated with the successful passage of legislation and effective governance more generally.

Substantively, the contents of a constitutional role morality should likely include general compliance with established political norms that advance constitutional purposes. ${ }^{165}$ To be sure, norms are "inherently provisional; they simultaneously settle presidential duty for a time and orient contestation over what acceptable behavior should be." 166 The same could be said of congressional norms. But surely certain norms are so well-established and serve such vital constitutional functions that a politician would require special justification to flout them. For example, routine lying by elected officials alienates the political opposition and makes political cooperation very difficult. Moreover, the obligation of elected officials to avoid some norm violations likely trumps the desire or duty to stay in office. The fact that norms are in the way does not furnish justification for violating them. They are supposed to be in the way.

The contents of a role morality should also likely include general compliance with "constitutional conventions" in the British (and, more generally, Commonwealth) sense of that term. As Keith Whittington has explained, constitutional conventions may be understood "as maxims, beliefs, and principles that guide officials in how they exercise political discretion." "167 Derived in substantial part from the historical practices of governmental institutions, they are non-legal in status but are experienced as obligatory. ${ }^{168}$ Unlike political conventions generally, moreover, constitutional conventions advance a purpose of the constitution. In the United States, such purposes include facilitating democratic self-government (as discussed above), ${ }^{169}$ creating

${ }^{165}$ For a discussion, see generally Siegel, supra note 27.

${ }^{166}$ Renan, supra note 27 , at 3.

${ }^{167}$ Keith E. Whittington, The Status of Unwritten Constitutional Conventions in the United States, 2013 U. ILL. L. REV. 1847, 1860. For additional discussions of constitutional conventions, see generally Siegel, supra note 27; Bradley \& Siegel, supra note 46, at 265-68; Michael C. Dorf, How the Written Constitution Crowds Out the Extraconstitutional Rule of Recognition, in THE Rule of RECOGNITION AND THE U.S. CONSTITUTION 69, 75 (Matthew D. Adler \& Kenneth Einar Himma eds., 2009); David E. Pozen, Self-Help and the Separation of Powers, 124 Yale L.J. 2, 29-39, 69 (2014); Mark Tushnet, Constitutional Hardball, 37 JoHn MARSHALL L. REV. 523,523 \& n.2, 544 (2004); and Adrian Vermeule, Conventions of Agency Independence, 113 COLUM. L. REV. 1163, 118194 (2013).

168 British commentator Albert Venn Dicey, writing during the late nineteenth century, viewed constitutional conventions as obligatory - as specifying how discretionary governmental power "ought to be exercised." A. V. Dicey, Introduction to the StUdy of THE LAW OF THE CONSTITUTION 346 (London, MacMillan \& Co. 3d ed. 1889).

169 The Constitution is not generally thought by experts to entitle registered voters to cast votes for Presidential electors. See U.S. Const. art. II, $\S 1$ ("Each State shall appoint, in such Manner as the Legislature thereof may direct, a Number of Electors ....."). Even so, a constitutional convention renders it unthinkable, except possibly in extraordinary circumstances, for a state legislature to appoint a slate of electors instead of allowing its registered voters to participate. Likewise, even though the Constitution is not generally thought by experts to prohibit members of the Electoral College from ignoring the popular vote for President in the states that appoint them, the overwhelming majority of electors throughout American history have not felt free to ignore the popular vote and cast their ballots for the candidate they personally prefer. See HERBERT W. HORWELL, THE USAGES OF THE AMERICAN CONSTITUTION 5, 7 (1925) (observing that the United States, like Great Britain, has various "customs, practices, maxims and precepts which are not enforced by the courts, and which thus correspond to the English [constitutional conventions]," and pointing as an example to "the understanding that Presidential Electors shall not 
an effective federal government (also discussed above), protecting judicial independence, ${ }^{170}$ and preventing the corruption of federal criminal law enforcement. ${ }^{171}$ To act contrary to a constitutional convention, as Whittington observes, "is to violate the spirit of the constitution, even if it does not violate any particular rule." ${ }^{172}$ The same could be said of disregarding constitutional role morality more generally.

A key advantage of deriving the substantive content of constitutional role morality in part from political norms and constitutional conventions is that it renders the normative inquiry analytically more tractable. Collective self-governance and an effective federal government help explain why role restraints are essential, but they are obviously abstract constitutional purposes. By contrast, the historical norms and practices of governmental institutions - and their procedural rules as well - can offer more determinate normative guidance. Their existence enables inductive, granular inquiries into the restraints that politicians have already developed for themselves over relatively long periods of time. They can be mined for normative guidance regarding the proper role of elected officials in the American system of government. ${ }^{173}$

Yet another qualification is required. Sometimes it may be necessary for presidents and members of Congress to violate even important norms and conventions. ${ }^{174}$ The great classics in the literature on political role morality (as a genre) have frequently taken the position that the morality of private life does not work in public life - that there is a disconnect between ordinary morality and political morality. The general thrust of this literature is that the stakes are so high in politics that the nicety of ordinary moral rules need to give way. On this view, consequences matter substantially more in the public realm than in the private realm because political decisions determine, for example, whether large numbers of people live or die, whether wars and economic

cast their votes according to their independent judgment but shall do no more than formally ratify the results of a previous popular vote").

${ }^{170}$ For example, even though the Constitution is not generally thought by experts to prohibit a party in control of Congress from expanding the size of the U.S. Supreme Court to pack it with partisan Justices, any such plan to increase the size of the Court would likely encounter intense bipartisan opposition. For a discussion, see Bradley \& Siegel, supra note 46, at 269-87. For a recent proposal to pack the lower federal courts with conservative Republican judges, see generally Steven G. Calabresi \& Shams Hirji, Proposed Judgeship Bill (Nov. 7, 2017), https:/thinkprogress.org/wp-content/uploads/2017/11/calabresi-court-packing-memo.pdf. For an explication of the proposal's profound anti-constitutionality, see Richard Primus, Rulebooks, Playgrounds, and Endgames: A Constitutional Analysis of the Calabresi-Hirji Judgeship Proposal, Harv. L. Rev. Blog (Nov. 24, 2017), https://blog.harvardlawreview.org/rulebooks-playgrounds-and-endgames-a-constitutional-analysis-of-the-calabresihirji-judgeship-proposal/.

${ }^{171}$ See, e.g., Siegel, supra note 27 (discussing the constitutional convention that prohibits the president from politicizing federal criminal law enforcement).

172 Whittington, supra note 167, at 1852. Likewise, under Dicey’s account, violating a constitutional convention is considered a breach of "constitutional morality." DICEY, supra note 168, at 346.

${ }^{173}$ Consider, for example, the procedural rules of the U.S. Congress. There are many ways in which a legislature may choose to structure such significant matters as member voting rules, committee operations, floor debates, and various balances of power (between the majority party and the minority party, between party leaders and the rank-and-file, and between committee chairs and committee members). Congress has made specific choices about those matters and many others.

${ }^{174}$ I thank Dick Fallon for emphasizing this point to me. 
depressions begin or end, and whether demagogues come to power or are defeated. ${ }^{175}$ While this view can easily be overstated or misused to rationalize troubling behavior by politicians, there is no doubt truth in the conviction that sometimes the stakes are so high in politics that even venerable norms and conventions must give way.

More controversially, federal politicians may bear some responsibility to practice moderation and compromise, at least presumptively. ${ }^{176}$ That responsibility may include some obligation not to take everything that they can get away with taking in an interaction with other politicians. ${ }^{177}$ Such self-restraint would likely require elected officials to adopt a longer-term institutional perspective and to possess a certain amount of respect for Americans on the other side of the issue under consideration. ${ }^{178}$ Cashing out substantive role expectations in that way can help maintain a meaningful level of social solidarity and cohesion. It can also help the federal government function more effectively and with greater stability. In a deeply polarized society, perhaps political steps should ordinarily be smaller in length and more cautious in placement. $^{179}$

To be plausible, however, a presumption in favor of moderation and compromise would have to be rebuttable and responsive to the extant conditions of political life. There have been times in American history when proposed forms of immoderacy and stridency were themselves

${ }^{175}$ See Niccolò Machiavelli, The Prince (Tim Parks trans. 2009) (1532); Max Weber, Politics as a Vocation, in From MAX Weber: EsSAYS IN Sociology 77-128 (Hans H. Gerth \& C. Wright Mills trans. \& eds., 1946) (1919); Michael Walzer, The Problem of Dirty Hands, 2 PHIL. \& PuB. Aff. 160 (1973); Thomas Nagel, Ruthlessness in Public Life, in PubliC and PrIvate MORAlity 75-91 (Stuart Hampshire ed., 1978). The relationship between private morality and public morality is a topic that is too rich and difficult for this Article to address.

${ }^{176}$ See Amy GutMAnn \& DenNis Thompson, The SPIRIT OF COMPROMise: Why Governing Demands IT AND CAMPAIGNING UNDERMINES IT 1 (2012) ("Compromise is difficult, but governing a democracy without compromise is impossible."); Jackson, supra note 14, at 1766 (arguing that, "for a multi-member, heterogeneous democratic legislative assembly, the 'spirit of compromise' is an essential attribute to get done the public's work of governing").

${ }^{177}$ That potential component of a restraining role morality for elected officials bears similarities to the idea of "fair play" in sports and due process jurisprudence. For a discussion, see Foley, supra note 42, at 686-93. Foley conceives of fair play as "a societal norm that constrains partisan competition." Id. at 688 . On his account, "[c]onduct of partisans that breaches the norm of fair play would be, intrinsically, an instance of excessive partisanship, or what we could call partisan overreaching." Id. at 688. Unlike this Article, Professor Foley does not distinguish legal from other restraints, perhaps because he seeks more vigorous judicial review of election laws.

${ }^{178}$ See GUTMANN \& THOMPSON, supra note 176, at 3 ("Resistance to democratic compromise can be kept in check by a . . . cluster of attitudes and arguments - a compromising mindset-which favors adapting one's principles and respecting one's opponents."). Cf. SUNSTEIN, supra note 15, at 50 (defending incompletely theorized judgments in part as an "effort[] to achieve both social stability and a degree of reciprocity, together with mutual respect, under conditions that threaten to endanger these important values").

${ }^{179}$ It is not necessary that every member of a plural body, whether Congress or a law school faculty, be willing to practice moderation and compromise. Indeed, members who articulate more extreme views can help hold moderates accountable for their compromises. What is necessary, however, is that there exist a core group of institutionalists who play that role and who are influential. Other components of constitutional role morality, such as not belittling members of the other political party or spreading falsehoods, should bind all members of the body. 
arguably justifiable. Reconstruction may be a good example. ${ }^{180}$ The New Deal may be another. The Civil Rights Era may be a third. There are issues, especially moral ones involving basic human dignity or equality guarantees or economic security, regarding which a president or member of Congress may not be able to compromise and must simply and entirely disappoint Americans on the other side.

One might go further and argue that immoderacy and stridency are always justifiable for the have-nots, precisely because tacit norms in the United States construct demands for justice as immoderacy and stridency. On that view, the lesson of past mobilizations is that norms of civility are just so much window dressing for status hierarchies. The claim is worth taking seriously, but it does not counsel rejecting the idea of a constitutional role morality for elected officials.

As an initial matter, the norms and conventions that apply to government officials may be different from the ones that apply to social movements and private activists. For example, it is at least plausible to think that movement activists, who do not represent their agonists or the nation as a whole, are justified in pushing harder for social change than most elected officials should be willing to push at a given point in time. Even assuming otherwise, not every past mobilization has succeeded only through immoderacy and stridency. For example, both the Civil Rights Movement and Second-Wave feminism involved a good deal of strategic incrementalism, compromise, and appeals to Americans on the other side of the issue in question. ${ }^{181}$ In addition, it is not clear why immoderacy and stridency are characteristically more likely to help traditionally excluded groups persuade Americans who possess power to take their claims seriously; immoderacy and stridency can also cause people of good will to recoil. Finally, this Article illustrates that norms of civility and related norms are not simply window dressing for status hierarchies. They also help make it possible for people with very different worldviews to go on living together by working out their conflicts without resorting to violence. ${ }^{182}$

That said, another, related caveat regarding compromise is warranted. It is critical for elected officials to bear in mind who is not in the room when compromises are hashed out. ${ }^{183}$ There are well-known instances in American history in which political compromises came at the expense of people who lacked economic and political power. For example, the celebrated historian G. Van Woodward described the plight of African Americans in the South after Reconstruction ended pursuant to a political compromise between Southern Democrats and the

${ }^{180}$ Even during Reconstruction, however, seven Republican senators refused to vote to remove President Andrew Johnson from office for patently partisan reasons. For a moving, detailed discussion of that episode, see Foley, supra note 42, at 693-708.

${ }^{181}$ See, e.g., Neil S. Siegel, "Equal Citizenship Stature”: Justice Ginsburg's Constitutional Vision, 43 NEW ENG. L. REV. 799, 843-53 (2009) (discussing Ruth Bader Ginsburg's characteristically incremental, moderate approach to realizing her constitutional vision of gender equality).

${ }^{182}$ Cf. Reva B. Siegel, Community in Conflict: Same-Sex Marriage and Backlash, 64 UCLA L. REV. (forthcoming 2017) ("Conflict channeled through the role understandings of constitutional culture is crucial in directing the growth and sustaining the authority of our constitutional law. . . For conflict to serve these ends, however, it must be constrained. Whether we ground these constraints in text, structure, or the unwritten Constitution, or call these constraints law, gloss, norms, or conventions, the vitality of these role constraints is key to the strength and to the character of a constitutional democracy.").

${ }^{183}$ I thank Ruth Colker for underscoring this point. 
Republican Party. ${ }^{184}$ "The determination of the Negro's 'place' took shape gradually," he wrote, "under the influence of economic and political conflicts among divided white people - conflicts that were eventually resolved in part at the expense of the Negro." ${ }^{\prime 85}$ In current times, potential compromises over gun control risk trading in false and damaging stereotypes about disabled Americans. ${ }^{186}$ Elected officials should always be alert to the possibility that proposed compromises reflect or reinforce the inferior social status of historically excluded groups in American society. ${ }^{187}$

Again, when to compromise and when to refuse is not a theoretical question; answering it in particular contexts requires political judgment. But much of the time on important policy issues, the above risks do not predominate and there are multiple, cross-cutting concerns, not all of which fracture Americans into two diametrically opposed camps. Alternatively, there is a broad level of agreement on the existence of a problem but sharp disagreement about how best to address it. In such circumstances, moderation and compromise are possible. It is often partisan identity and an aversion in principle to compromise that get in the way.

One final qualification is needed, and it is an important one. In developing a constitutional role morality for elected officials of the federal government, a persistent problem lies in balancing words like "modest," "experimental," and "pragmatic" with the possibility of a dramatic political shift that is legitimated by a special democratic warrant to act. Bruce Ackerman's influential theory of constitutional moments is built around the possibility of supermajorities, over sustained periods of time, with clear statements of objectives and stakes. ${ }^{188}$ Whether Ackerman is right or wrong about the grounds of legitimate constitutional change, he is surely right that strong, sustained supermajority support is relevant to politically

${ }^{184}$ C. VAnn Woodward, The Strange Career of Jim Crow 6 (3d rev. ed. 1974). The Compromise of 1877 , as it was called, required Southern Democrats to withdraw their support for Democrat Samuel J. Tilden, who they argued had been elected president, and instead to support Republican Rutherford B. Hayes, in exchange for the end of Reconstruction. As Vann Woodward wrote, "[t]he phase that began in 1877 was inaugurated by the withdrawal of federal troops from the South, the abandonment of the Negro as a ward of the nation, the giving up of the attempt to guarantee the freedman his civil and political equality, and the acquiescence of the rest of the country in the South's demand that the whole problem be left to the disposition of the dominant Southern white people." Id.

${ }^{185} \mathrm{Id}$.

186 See, e.g., David Perry, Paul Ryan's “Mental Health” Focus Is a Sham, CNN (Oct. 5, 2017), http://www.cnn.com/2017/10/05/opinions/paul-ryan-mental-health-guns-sham-david-perry/index.html (“Only 3\% to $5 \%$ of all violent crimes involve people with psychiatric disabilities, including conditions such as schizophrenia or bipolar disorder. People with such conditions make up more than $18 \%$ of the American population. These individuals are 10 times more likely to be victims of violence than those without mental illness."). For a broader and more scholarly argument that singling out individuals with mental disorders for disparate treatment is often unjustified, see generally Sherry F. Colb, Insane Fear: The Discriminatory Category of "Mentally Ill and Dangerous, ” 25 New ENG. J. ON CRIM. \& CiV. CONFINEMENT 341 (1999).

187 This concern partially animates the insistence of critical theorists that members of historically subordinated groups be included in the composition of legislatures in sufficient numbers to potentially impact legislative outcomes. For prominent expressions of that insistence or of related concerns about the suppression of minority voices in the legislative process, see generally LANI GUINIER, THE TYRANNY OF THE MAJORITY: Fundamental Fairness and Representative Democracy (1994); Melissa Williams, Voice, Trust, and MEMORY: MARginALIZED GROUPS AND THE FAILING OF LIBERAL REPRESENTATION (1998); IRIS MARION YOUNG, Justice AND the Politics of DiffERence (1990); and Iris MARION Young, InClusion AND DeMOCRACY (2000).

${ }^{188}$ See supra note 14 (citing Ackerman's relevant works). 
appropriate change - and therefore, to how restraining a role morality for elected officials should be at a particular point in political time. But radical and dramatic change is the exception in American politics, not the rule. And the circumstances of American politics today approach the antithesis of the circumstances that Ackerman describes as licensing radical change.

\section{What about the Affordable Care Act?}

The Patient Protection and Affordable Care Act (ACA) was the most significant legislative legacy of Democratic President Barack Obama. ${ }^{189}$ A Democratic Congress passed the statute over vehement Republican opposition, ${ }^{190}$ and without a single Republican vote, ${ }^{191}$ notwithstanding the fact that it was the most significant expansion of the social safety net in the United States in almost half a century. ${ }^{192}$ In addition, congressional Democrats ultimately resorted to an unconventional legislative process in order to enact the law. ${ }^{193}$ According to public opinion polls, moreover, popular majorities opposed the statute for years, and the ACA achieved majority support in the nation only recently, as it was being threatened with repeal by a Republican president and Congress. ${ }^{194}$ Most Americans continue to believe that parts of the law

${ }^{189}$ Pub. L. No. 111-148, 124 Stat. 119 (2010) (codified as amended in scattered sections of 26 and 42 U.S.C.); see Health Care and Education Reconciliation Act of 2010, Pub. L. No. 111-152, 124 Stat. 1029 (2010).

${ }^{190}$ See Walker Ray \& Tim Norbeck, A Look Back at How the President Was Able to Sign Obamacare into Law Four Years Ago, ForBes (Mar. 26, 2014), https:/www.forbes.com/sites/physiciansfoundation/2014/03/26/alook-back-at-how-the-president-was-able-to-sign-obamacare-into-law-four-years-ago/\#164e481d526b

("Republicans invoked Thomas Jefferson's observation that 'great innovations should not be forced on a slender majority - or enacted without broad support.' They cited broad legislative innovations like Social Security and Medicare, both of which enjoyed bipartisan support. They complained that one fewer vote in the Senate or a change of four votes in the House would have been enough to defeat ObamaCare.")

191 See, e.g., Shailagh Murray \& Lori Montgomery, House Passes Health-Care Reform Bill without Republican Votes, WASH. POST (Mar. 22, 2010), http://www.washingtonpost.com/wpdyn/content/article/2010/03/21/AR2010032100943.html.

192 See, e.g., The StafF of the Washington Post, LANDMARK: THE Inside Story OF AMERICA'S NEW HeAlth-CARe LAW AND What It MeANS FOR Us All 66-67 (2010) [hereinafter LANDMARK] (calling the ACA "the biggest expansion of the social safety net in more than four decades, providing greater economic security to millions of poor and working-class families").

193 See, e.g., King v. Burwell, 135 S. Ct. 2480 (2015):

Congress wrote key parts of the Act behind closed doors, rather than through "the traditional legislative process." And Congress passed much of the Act using a complicated budgetary procedure known as "reconciliation," which limited opportunities for debate and amendment, and bypassed the Senate's normal 60-vote filibuster requirement.

Id. at 2492 (quoting and citing John Cannan, A Legislative History of the Affordable Care Act: How Legislative Procedure Shapes Legislative History, 105 L. LIBR. J. 131, 159-67 (2013)).

${ }^{194}$ See Hannah Fingerhut, Support for 2010 Health Care Law Reaches New High, PEW RESEARCH CENTER (Feb. 23, 2017), http://www.pewresearch.org/fact-tank/2017/02/23/support-for-2010-health-care-law-reaches-newhigh/ (finding that Americans approve the ACA by a margin of 54 to 43 percent, and that "[f]or the first time, [the] 2010 health care law draws majority approval”); Quinnipiac University Poll, March 8, 2017, at 6 [hereinafter March 2017 Quinnipiac Poll], https://poll.qu.edu/national/release-detail?ReleaseID=2437 (finding that Americans think "Donald Trump should [not] support efforts to repeal the Affordable Care Act" by a margin of 51 to 45 percent). 
should be repealed (while other parts should be kept). ${ }^{195}$ Given all of those considerations, how could it have been consistent with the constitutional role morality just sketched for Democratic politicians to have passed the ACA? If a role morality for elected officials has any bite at all, then should it not have counseled against passage of that law?

Those are fair questions, and they deserve an answer, particularly from a scholar who devoted much time to defending the constitutionality of the law. ${ }^{196}$ But the importance of the questions far transcends the continued controversy surrounding the ACA. A more general way to frame the issue is whether widespread adoption of a constitutional role morality for elected officials would rule out major, controversial actions by the federal government. If elected officials acted the way this Article would have them act, could Congress still pass a statute like the ACA? If so, would it need to follow a different process from the one the ACA Congress followed?

Although reasonable minds will differ about what constitutional role morality required of Democratic politicians given the considerations described above, the most persuasive answer (in this author's view) is not what is implied by the selective arrangement of the facts previously noted. The ACA was not a partisan innovation or bolt from the blue; on the contrary, it was the culmination of many decades of failed attempts at bipartisan health care reform. ${ }^{197}$ Moreover, the White House and Democratic leaders made efforts to reach out to Republican members of Congress rhetorically and procedurally, and Democrats incorporated some of the Republicans' past and present substantive ideas. ${ }^{198}$ In addition, Democratic leaders held numerous public hearings, developed an extensive legislative record, and voted after the Congressional Budget Office scored the various bills. In the end, the process entailed more than a year of legislative

195 See March 2017 Quinnipiac Poll, supra note 194, at 9 (finding that 21 percent of Americans think "President Trump and the Republicans in Congress should repeal all of the Affordable Care Act, also known as Obamacare"; that 49 percent think they "should repeal parts of the healthcare law but keep other parts"; and that 27 percent think they "should not repeal any of the Affordable Care Act").

${ }^{196}$ See generally, e.g., Robert D. Cooter \& Neil S. Siegel, Not the Power to Destroy: An Effects Theory of the Tax Power, 99 VA. L. REV. 1195 (2012); Siegel, Free Riding on Benevolence, supra note 134; Neil S. Siegel, Four Constitutional Limits that the Minimum Coverage Provision Respects, 27 CONST. COMMENT. 591 (2011).

197 See, e.g., Robert B. Reich, Critical Care, N.Y. TIMES (Sept. 1, 2009), http://www.nytimes.com/2009/09/06/books/review/Reich-t.html (reviewing DAVID BLUMENTHAL \& JAMES A. Morone, The Heart of Power: Health and Politics in the Oval OfFice (2010)) ("Universal health care has bedeviled, eluded or defeated every president for the last 75 years."); King, 135 S. Ct. at 2485 (observing that the ACA "grew out of a long history of failed health insurance reform").

198 See, e.g., Norm Ornstein, The Real Story of Obamacare's Birth, THE ATLANTIC (July 6, 2015), https:/www.theatlantic.com/politics/archive/2015/07/the-real-story-of-obamacares-birth/397742/ (discussing the efforts of key Senate Democrats to begin with Republican ideas and proceed on a bipartisan basis, and documenting the eventual refusal of Senate Republicans to participate in such a process); Glenn Kessler, History Lesson: How the Democrats Pushed Obamacare through the Senate, WASH. Post (June 22, 2017), https:/www.washingtonpost.com/news/fact-checker/wp/2017/06/22/history-lesson-how-the-democrats-pushedobamacare-through-the-senate/?utm_term=.1231f4956427 ("Democrats at first tried to enlist some Republican support, while Republicans have not reached out to Democrats."); LANDMARK, supra note 192, at 68 (noting that the ACA is a "market-based approach" that "bears clear resemblance to the leading Republican alternative to the Clinton plan, to proposals developed by the conservative Heritage Foundation, and to the 2006 legislation signed by Republican Governor Mitt Romney that created universal coverage in Massachusetts”). 
effort and public scrutiny. ${ }^{199}$ The procedural shortcuts for which Democrats deserve blame in passing the ACA pale in comparison to how Republicans have since repeatedly proceeded in attempting to repeal and replace the law. ${ }^{200}$ And because substance matters too in assessing what role morality requires of politicians in particular circumstances, it is also relevant that the statute seeks to address what is fairly described as a human tragedy and serious economic problem: tens of millions of Americans who lack health insurance and thus access to basic, affordable health care. $^{201}$

There is more. Parts of the law have always been popular (namely, the provisions that protect people from being denied coverage based on pre-existing conditions or charged higher premiums based on medical history), and those parts are tied functionally to the provision of the law that was probably least popular (the so-called individual mandate). ${ }^{202}$ Those facts may suggest that much of the public did not understand how the statute was designed to work. Even now, unified Republican government has resulted in repeated failures to repeal the law, ${ }^{203}$ although the individual mandate was repealed by the recently enacted tax law. ${ }^{204}$ To reiterate,

${ }^{199}$ See, e.g., Brian Beutler, Republicans Thinks Capitol Hill's Rules Are for Suckers, NeW REPUBLIC (Jan. 9, 2017), https://newrepublic.com/article/139707/republicans-think-capitol-hills-rules-suckers ("Obamacare was likely the most scrutinized major legislation in U.S. history-the product of thousands of man hours of committee work, crafted with the expectation that a neutral Congressional Budget Office would analyze its effect on deficits and health spending growth. It took over a year to complete, and while the reconciliation process was a key part of the bargain among Democrats to enact the law, they passed health care reform itself over a GOP filibuster with 60 votes.").

${ }^{200}$ See, e.g., Thomas Kaplan \& Robert Pear, Senate Republicans Say They Will Not Vote on Health Bill, N.Y. TIMES (Sept. 26, 2017), https://www.nytimes.com/2017/09/26/us/politics/mcconnell-obamacare-repealgraham-cassidy-trump.html?_r=0 (quoting Republican Senator Lisa Murkowski of Alaska, who denounced what she described as "a lousy process" and further stated that "[t]he U.S. Senate cannot get the text of a bill on a Sunday night, then proceed to a vote just days later, with only one hearing - and especially not on an issue that is intensely personal to all of us"); Kessler, supra note 198 ("The biggest difference between the Democratic effort to reshape health care in 2009-2010 and the Republican effort to undermine that achievement is that the Democrats made full use of the committee process. Republicans have skipped the days of hearings and lengthy markups that were a feature of the crafting of Obamacare."); Reich, supra note 197 (noting that "the cost estimates of the Congressional Budget Office set [President Obama] back").

${ }^{201}$ According to the U.S. Census Bureau, around nineteen percent of the nonelderly population, or roughly fifty million people, lacked health insurance in 2009. U.S. Census Bureau, Income, Poverty, and Health Insurance Coverage in the United States: 2009, at 23 (2010).

${ }^{202}$ For a discussion, see Siegel, Free Riding on Benevolence, supra note 134, at 38-40. In brief, the financial incentive to purchase insurance combats the perverse incentive people would otherwise have to wait until they were ill to get insured in a regime in which they could no longer be denied coverage or charged more for already being sick. See id.

${ }^{203}$ See, e.g., Sheryl Gay Stolberg, McConnell Gambled on Health Care and the Alabama Senate Race. He Lost., N.Y. TIMES (Sept. 27, 2017), https://www.nytimes.com/2017/09/27/us/politics/mcconnell-gambled-on-healthcare-and-the-alabama-senate-race-he-

lost.html?rref=collection $\% 2$ Ftimestopic $\% 2$ FHealth $\% 20$ Care $\% 20$ Reform\&action=click\&contentCollection=timestop ics\&region $=$ stream $\&$ module $=$ stream_unit\&version=latest\&contentPlacement $=2 \& p g t y p e=$ collection .

${ }^{204}$ See, e.g., Joel Dodge, Can Obamacare Survive Without the Individual Mandate?, NEW REPUBLIC (Jan. 3, 2018), https://newrepublic.com/article/146462/can-obamacare-survive-without-individual-mandate. 
there were key parts of the ACA's drafting process that left much to be desired, ${ }^{205}$ but others did not and, overall, it does not seem an abuse of political power for the Democrats to have eventually decided to go it alone. After decades of failure and unwavering Republican opposition at the time, it would likely have been asking too much of the Democrats to wait another decade or more to achieve their objective of helping the uninsured. A constitutional role morality is not infinitely constraining, but that does not mean it is not constraining at all.

Other commentators will no doubt disagree with the above analysis. Dissensus will likely be attributable in part - but only in part - to substantive disagreements about the wisdom or constitutionality of the ACA. Just as questions of judicial role generate robust disagreements, ${ }^{206}$ so will issues of political role if the idea of a constitutional role morality takes hold. Such disagreements are, to a substantial extent, healthy-far healthier than simply assuming or asserting the absence of a constitutional role morality applicable to elected officials. Disagreement generates dialogue, and dialogue helps fashion and fortify the very role restraints whose applicability is at issue. ${ }^{207}$

To be sure, disagreement is not only healthy. The risk is that a common commitment to the idea of a constitutional role morality will end up recapitulating the very partisan conflicts it is attempting to temper. ${ }^{208}$ It may be unduly pessimistic, however, to conclude that such a common commitment would be both genuine and completely unrestraining. Forcing politicians to justify their conduct in terms of constitutional role morality-in terms of due regard for the political opposition, the nation as a whole, and the institutions in which they serve-would itself be an improvement over the status quo. As discussed above, ${ }^{209}$ rhetoric helps shape reality, and in any event, requiring such justificatory rhetoric would help "smoke out" excessively partisan purposes. Just as Republicans condemned parts of the process through which the ACA was enacted, so Democrats are currently demanding public-spirited justifications from Republicans. And Republicans may again be asking the same of Democrats after the 2018 and 2020 elections.

${ }^{205}$ See, e.g., Kessler, supra note 198 (noting that the long floor debate on the ACA "was mostly for show, an exercise designed to allow the closed-door negotiations that shaped the final bill to take place," and that "[o]nce the deal was struck, [Senate Majority Leader Harry] Reid pushed the final draft forward with as much speed as possible").

206 See, e.g., Green, supra note 51, at 661 ("Conversations about judicial role do not yield an image of cultural consensus, much less of unanimity. Our variegated legal community is populated by judges, lawyers, and commentators who differ widely over how judges do and should act.").

${ }^{207} C f$. id. at 660 ("To discuss judicial behavior fosters a dialogue about the limits of judicial role that itself serves to construct such limits and give them force.").

${ }^{208}$ For analysis of the related phenomenon of theory "working itself impure," see generally Jeremy K. Kessler \& David E. Pozen, Working Themselves Impure: A Life Cycle Theory of Legal Theories, 83 U. CHI. L. REV. 1819 (2016).

${ }^{209}$ See supra note 161 and accompanying text. 


\section{Role AlLocations}

Constitutional law scholarship that further develops a role morality for elected officials will have implications for how different actors in the American constitutional system should execute their professional responsibilities if they are to make it more likely that such a role morality will eventually be embraced and sustained. This Part examines those implications and actors. In addition to politicians themselves, they include citizens broadly, school teachers, law teachers, and Americans who oppose aggressive action by a presidential administration or Congress.

\section{A. $\quad$ Elected Officials and Citizens}

The challenge for elected officials is to consider not just the legal authority that they possess as a result of formal electoral processes, but also the political authority that they can acquire only from reaching out to a broader range of Americans than their political base. Just as non-legal but presumptively obligatory norms of the system may require judges to moderate in various ways, so elected officials should come to respect a role morality something like the one sketched in Part III. Of course, such norm internalization by politicians is unlikely in the shortto-medium run. For example, no one should expect President Trump, senior members of his administration, or congressional Republicans to be much moved by arguments that they are obliged to moderate. One should expect some Republicans and Democrats up for re-election in 2018 or 2020 who do not occupy safe seats to conclude that it is in their political self-interest to moderate with respect to some issues. But the pursuit of political self-interest is not the same phenomenon as the internalization of a political norm. ${ }^{210}$

Given the short-to-medium term prospects for success, arguments of the sort being tendered in this Article are easily dismissed as being suggested by electoral losers and ignored by elector winners. Yet such arguments may also fall on deaf ears in the case of assertive jurists. Even so, it is worth repeating the point of Part I: generations of constitutional law scholars, law teachers, and other participants in American constitutional discourse have made such arguments to judges all the while knowing that many judges, including pivotal Justices, may be unwilling to heed them. The hope seems to have been that in general, over the long run, and at certain key moments, such arguments may make an important difference. ${ }^{211}$ It does not seem entirely fair to dismiss as electoral losers legal scholars and others who "hold onto a set of expectations for lawyers, politicians, judges, or legal scholars like themselves, even in the face of evidence that those expectations frequently and repeatedly go unmet." ${ }^{212}$ Relatedly, it does not seem accurate

${ }^{210}$ See, e.g., Richard H. Fallon, Jr., Constitutional Precedent Viewed through the Lens of Hartian Positivist Jurisprudence, 86 N.C. L. REV. 1107, 1115 (2008) ("Equilibria are not norms, and I doubt that law could exist in the absence of anyone having a normative commitment to obeying it."); Siegel, supra note 27 (distinguishing political norms from game theoretic "equilibria").

${ }^{211}$ For one possible such instance in recent years, see generally Neil S. Siegel, More Law than Politics: The Chief, the “Mandate," Legality, and Statesmanship, in THE HEALTH CARE CASE: THE SUPREME COURT'S DECISION AND ITS IMPLICATIONS 192-214 (Nathaniel Persily, Gillian E. Metzger \& Trevor W. Morrison eds., 2013). 290 (2013).

${ }^{212}$ Charles L. Barzun, Getting Substantive: A Response to Posner and Vermeule, 80 U. CHI. L. REV. 267 , 
to charge this Article with making inconsistent assumptions about what motivates government officials. ${ }^{213}$ The Article is arguing that more public-regarding and institution-minded motivations from elected officials would better sustain the constitutional system. It is hardly assuming that elected officials will be so motivated any time soon just because it would be valuable for them to be so motivated.

In order to eventually instill such normative expectations in politicians, it is essential to also try instilling them in their constituents (not to mention the donors, party officials, media outlets, and others who constitute the environment in which elected officials must function). How to do so is beyond this author's expertise and the sphere of influence of constitutional law scholars more generally. That said, enhancing civic education for young Americans (contrary to current trends) seems like a good idea, as important as STEM fields also are, and as naïve as the suggestion may sound. ${ }^{214}$ Imagine teaching the next several generations of schoolchildren that voters, like elected officials, soldiers, and jurors, hold an important public office, and that as trustees, they are "charged with the responsibility of acting on behalf of society as a whole, present and future." 215 Figuring out ways to reach the broader public and other players who surround elected officials would, among other virtues, afford politicians some normative "space" in which to function in a more public-regarding and institution-minded way.

\section{B. Law Teachers}

If politicians are going to learn such lessons over the longer run, then others are going to have to teach them when they are younger and more impressionable. A noble charge for law teachers, including constitutional law teachers, would be for them to develop ideas, curricula, and methods aimed at instructing future political leaders - not just future judges - that a constitutional role morality applies to them. ${ }^{216}$ More generally, law teachers might impress upon their students the point that federal judges and elected officials are not only different (although

${ }^{213}$ See generally Eric A. Posner \& Adrian Vermeule, Inside or Outside the System?, 80 U. CHI. L. REV. 1743 (2013) (criticizing scholars who first adopt the "external" perspective of political scientists by assuming that government officials pursue their self-interest, and then propose to solve the problems such self-interest creates by adopting the "internal," normative perspective of law professors - a solution whose success requires governmental officials (usually judges) to act in the public interest, not their own).

${ }^{214}$ See Edward B. Foley, Voters as Fiduciaries, 2015 U. CHI. LEGAL F. 153, 190 (2015) (emphasizing the need to "put in place a curriculum that prepare[s] citizens appropriately for the fiduciary responsibility of being a voter," so that "[c]ivics education ... . would not be shunted as an afterthought, subordinated to the so-called 'STEM' subjects of science, technology, engineering, and math').

${ }^{215} I d$. at 162-63; see id. at 163 ("Just as any other trustee breaches his or her fiduciary duty when using the trust's assets to promote the trustee's own personal self-interest, so too voters breach their fiduciary duties to society as a whole, present and future, if they exploit the electorate's power over the assets of the commonwealth to promote their own personal self-interest."). Professor Foley makes the intriguing suggestion of adopting a "voter's oath" analogous to the oaths that legislators must affirm. Id. at 191.

${ }^{216}$ Cf. Joe Palazzolo, In Short Supply in Donald Trump's Cabinet: Lawyers, WALl ST. J. (March 2, 2017), https://www.wsj.com/articles/in-short-supply-in-donald-trumps-cabinet-lawyers-1488463200 (quoting legal scholar Craig Green as stating that "[l] egal training orients people toward tradition and institutions, directing them to think about change in an incremental way and to explain and justify the way things are"). 
they are); they are also, in certain key respects, more similar than has traditionally been thought by constitutional law scholars. Both sets of actors possess, or should possess, role restraints on their pursuit of substantive objectives. And in both realms, fundamental questions arise about how it is appropriate to use the power one possesses in the face of broad and deep disagreement. Law teachers could also engage their students as citizens, not just future lawyers and political leaders, and instruct them that high levels of polarization and animus between members of the two main political parties imperil the constitutional system.

This Article has examined the role responsibilities of presidents and members of Congress by asking into the relationship between various kinds of restraints on partisanship and the accomplishment of vital constitutional purposes. There are, of course, other ways to theorize and teach about the role restraints, or lack thereof, that attach to political office. As discussed above, the great classics of political morality have tended to argue that the stakes are so high in politics that ordinary morality must give way. ${ }^{217}$ By contrast, Arthur Applbaum, in his seminal book on role morality, argues that political, legal, and business "[i]nstitutions and the roles they create ordinarily cannot mint moral permissions to do what otherwise would be morally prohibited." 218

Scholars of the legal profession are also focused on issues of role morality. For example, W. Bradley Wendel describes truthfulness in public life as "an ethical ideal," and he argues that "[s]eeking to learn the truth and communicate it accurately to other people are virtues that are necessary to a common form of life characterized by trust, respect, and the protection of human dignity" 219 Moreover, there is an important sub-debate in the literature about the role morality of government lawyers. During the Bush administration, for example, there was much thinking about their role morality, especially in the Justice Department's Office of Legal Counsel. ${ }^{220}$

In addition to work on role morality, writing on leadership is pertinent to scholarship and teaching that means to educate future politicians during their time in law school. There have traditionally been many ideas about, and accounts of, leadership in such disciplines as law, sociology, and history. ${ }^{221}$ There is also much modern research on leadership in a number of

${ }^{217}$ See supra notes 174-175 and accompanying text (discussing the relevant works).

${ }^{218}$ See Arthur Isak Applbaum, Ethics for AdVersaries: The Morality of Roles IN PUblic AND PROFESSIONAL LIFE 3 (1999).

${ }^{219}$ W. Bradley Wendel, Truthfulness as an Ethical Form of Life, DUQUESNE U.L. REV. (forthcoming 2018).

${ }^{220}$ See, e.g., DAVID LuBAn, Torture, POWER, AND LAW 195-306 (2014) (discussing the complicity of government lawyers in torture).

${ }^{221}$ See generally, e.g., Anthony T. Kronman, The Lost Lawyer: FaILING Ideals of the Legal Profession (1993); PhILIP SELZNICK, LEADERShIP IN ADMINISTRATION: A SOCIOLOGICAL INTERPRETATION (1957); Alexis De Tocqueville, Democracy IN America 150-51 (J.P. Mayer ed., George Lawrence trans., 1969) (arguing that because the "immense" "power" of the Supreme Court "spring[s] from opinion," Justices "must not only be good citizens and men of education and integrity, qualities necessary for all magistrates, but must also be statesmen; they must know how to understand the spirit of the age, to confront those obstacles that can be overcome, and to steer out of the current when the tide threatens to carry them away, and with them the sovereignty of the Union and obedience to its laws"). 
fields. ${ }^{222}$ Academic research on leadership may sit in fascinating tension with the basic insight that "[c]ontext is everything" in determining what leadership requires in a particular situation. ${ }^{223}$

Also relevant are potential historical exemplars of leadership or its antithesis in politics, both in the United States and in other democracies. ${ }^{224}$ Those exemplars could be developed as case studies, in much the way that certain judicial biographies and judicial decisions serve as case studies of success or failure in fulfilling the responsibilities of the judicial role. ${ }^{225}$ The discussions of Burke, Madison, Washington, and Jefferson in this Article, which draw upon the views of some of the most widely respected and venerable political figures from the American Founding (if one is not examining issues of race or gender), can be understood as gestures in a profitable direction. And there are no doubt numerous "contra" examples from different historical eras that could be analyzed. There is room for such discussions in constitutional law classes, particular if the professor emphasizes the role of constitutional interpretation and leadership outside the courts. For example, one leading casebook includes excerpts of historic addresses or writings by Frederick Douglass, Abraham Lincoln, Jacob Howard, Susan B. Anthony, Franklin Delano Roosevelt, Martin Luther King, Jr., John F. Kennedy, Hubert H. Humphrey, Everett McKinley Dirksen, and Lyndon B. Johnson, among others. ${ }^{226}$

So as not to become discouraged, law professors (as well as other academics and nonacademics) who accept this invitation will have to keep their expectations relatively modest, at least in the short-to-medium run. Legal academics have greater influence over judges than they do over legislators and executive officials, for at least two reasons. First, all judges, but only some legislators and executive officials, are lawyers. Second, notwithstanding complaints by Chief Justice John Roberts, D.C. Circuit Judge Harry Edwards, and some other judges about the uselessness of law review articles to judges, ${ }^{227}$ many judges (including in all likelihood the Chief

${ }^{222}$ See generally Deborah L. Rhode, Leadership in Law, 69 STAN. L. REV. 1603 (2017) (arguing that law schools must do more to prepare students for the leadership positions that lawyers disproportionately occupy and reporting key findings of contemporary research on leadership). To its credit, the Stanford Law Review recently held a symposium on leadership in law. See generally Sophie J. Hart, Introduction to "Raising the Bar: Lawyers and Leadership," 69 STAN. L. REV. 1593 (2017) (describing the symposium gathering and written contributions).

${ }^{223}$ Robert Post, Leadership in Educational Institutions: Reflections of a Law School Dean, 69 STAN. L. REV. 1817, 1817 (2017). See id. ("I have no doubt that we can acquire a great deal by the study of leadership. But my own intuition is that leadership is more a verb than a noun. It is evidenced in actions appropriate to ambient circumstances. Leadership is like the right key sliding into the right lock.").

${ }^{224}$ See, e.g., Burke, supra note 79.

${ }^{225}$ See supra notes 52-55 and accompanying text (discussing the uses that legal academics make of judicial biographies and judicial decisions).

226 Paul Brest et Al., Processes of Constitutional Decisionmaking: CASes And Materials 29297, 309-10, 332-33, 354-61, 395-96, 626-30, 632-34, 649-53, 662-66 (6th ed. 2015).

${ }^{227}$ See Law Prof. Ifill Challenges Chief Justice Roberts' Take on Academic Scholarship, ACSBLOG (July 5, 2011), https://www.acslaw.org/acsblog/law-prof-ifill-challenges-chief-justice-roberts\%E2\%80\%99-take-onacademic-scholarship (noting that at the 2011 Fourth Circuit Judicial Conference, "Roberts claimed that legal scholarship is not relevant to the work of lawyers and judges, saying he is on the same page with Judge Harry T. Edwards of the U.S. Court of Appeals for the D.C. Circuit, who believes there is a great 'disconnect between the academy and the profession"'). 
Justice) in fact consult at least some of the law review literature. ${ }^{228}$ More generally, judges care about maintaining a good relationship with the legal academy for reasons that may not apply as readily to members of the elected branches. Those reasons include shared intellectual interests and the fact that the law schools supply law clerks.

Still, law schools could develop a more robust relationship with the political branches by reconceptualizing them in the way this Article proposes, even if that relationship would still not be as close as it is with the judiciary any time soon. Law schools could also cultivate a closer relationship with the political branches by developing more of a practice of sending their graduates to serve members of Congress and executive branch officials, in addition to judges. For example, a step in the right direction would be passage of the Congressional Clerkship Act, which would create a congressional version of the federal judicial clerkship program. Proponents of the Congressional Clerkship Act seek to address the general lack of legislative work experience among members of the legal profession and to help bridge the divide between the legislative and judicial branches. ${ }^{229}$ Were members of Congress to take it seriously as a way of accessing young legal talent, a congressional clerkship program would also have the virtue of developing closer ties between the legal academy and Congress.

\section{The Opposition}

Finally, the vision offered in this Article has implications for practices of political resistance. Few engaged participants in the constitutional system would be persuaded to accept aggressive judicial behavior based only on such statements as "appointments have consequences" or "it's just judging" for federal judges to strongly advance ideological agendas. Likewise, it is not clear why opposition politicians, members of the news media, the institutions of civil society, and concerned citizens should accept as conversation stoppers assertions by those in political power or their defenders that "elections have consequences" or "it's just politics" for politicians to forcefully advance ideological agendas. They should instead regard themselves as entitled to vigorously contest the constitutional legitimacy of exercises of partisan political power when elected officials seek to justify acting in narrowly partisan ways by invoking the outcome of the previous election.

The closest one observes to such pushback in contemporary political discourse can be found in debates over whether a new president is "legitimate" or has a "mandate" to govern. Debates over whether a particular president is "legitimate," however, often miss the distinction between legal legitimacy and what this Article terms constitutional legitimacy. Legal legitimacy for a president inheres in winning a sufficient number of votes in the Electoral College. Constitutional legitimacy, it is worth repeating, cannot be earned by winning only bare majority

${ }^{228}$ See generally, e.g., Neal Kumar Katyal, Foreword: Academic Influence on the Court, 98 VA. L. REV. 1149 (2012).

${ }^{229}$ See Congressional Clerkship Coalition: A Legislative law Clerk Program for the U.S. CONGRESS, http://www.congressionalclerkship.com/; see also Abbe Gluck \& Dakota Rudesill, Introducing the Congressional Clerkship, BALKINIZATION (Dec. 8, 2016), https://balkin.blogspot.com/2016/12/introducingcongressional-clerkship.html. 
support, let alone minority support, throughout the nation for the lion's share of one's policies, priorities, and conduct in office. As for whether a new president has a "mandate" to govern, that is one good question to ask because the existence of a mandate can be interpreted as implying a certain level of inclusivity beyond bare majority support. But even the existence of a genuine electoral mandate (an unlikely phenomenon in current times) should not free elected officials to ignore their political opponents or the best interests of the institutions in which they serve.

Fully appreciating that a constitutional role morality applies to elected officials holds the potential to catalyze - and to legitimate - practices of robust, confident political resistance. Role restraints on presidents and members of Congress can serve as a constitutional anchor point for the full-throated expression of such resistance and would help inspire Americans not to relent when they are advised that "elections have consequences." Elections do have consequences, but those consequences may in particular instances not be what those who utter that statement mean to imply. Rather than stopping a conversation about the exercise of political will, the idea that elections have consequences should invite a conversation about what, exactly, the previous election has settled — and what it has not.

\section{OBJECTIONS}

This Part anticipates two objections to this Article's project. The first is that constitutional law scholars should not focus on developing a constitutional role morality for elected officials, but should instead work on redesigning the institutional environments within which politicians operate. The second objection, already anticipated in Part IV.A, is that the vision set forth in this Article faces severe implementation problems.

\section{A. $\quad$ First Objection: Institutional Structure, Not Role Morality}

This Article may be faulted for focusing on the development of role restraints of questionable enforceability, and not on the redesign of the institutional environments within which elected officials operate. Policing partisan gerrymanders, for example, would obviously change the incentives of many members of the House of Representatives. ${ }^{230}$ And there are a variety of new laws that a future Congress could pass, and a future president could sign into law, that would enshrine various role restraints into law-for example, statutes requiring presidential candidates to release their tax returns and divest of their business holdings. On the state level, open primaries would combat partisan extremism. Why emphasize an ineffective role morality instead of a more effective set of rules and structural reforms?

The most important response to this objection is that the two approaches are not mutually exclusive. Role restraints should be viewed as a complement to, not a substitute for, work that proposes new rules and a reconfiguration of governmental institutions. Given the magnitude of

${ }^{230}$ See supra note 62 and accompanying text (noting the countermajoritarian effects of partisan gerrymandering). 
the self-governance and collective action problems facing the nation, a both-and approach is preferable anyway to focusing exclusively on one or the other. The two approaches are also related in that politicians who have, to some degree, internalized a role morality of the sort championed in this Article are most likely to support public-spirited rules and structural reforms. James Madison may have been right in Federalist 51 to emphasize institutional architecture first and role restraints second, ${ }^{231}$ but it may be worth repeating that he placed significant value on both. ${ }^{232}$ Notwithstanding statements like those in Federalist 51 that "[a]mbition must be made to counteract ambition" and "[ $\mathrm{t}]$ he interest of the man must be connected with the constitutional rights of the place,"233 Madison did not believe that it would suffice for elected representatives to possess little or no virtue or regard for the public good. Nor should Americans so believe today.

Another response is that rules and structures by themselves are very unlikely to succeed without elected officials who are, to some non-trivial extent, properly normalized into a role. There are just too many ways of successfully violating or circumventing rules and structures or of behaving badly within the zones of discretion that they sensibly confer in order to enable adaptation to unforeseeable circumstances. As legal scholar Justin Levitt writes, "[s]ubstantive rules and institutional structure alone are insufficient to constrain certain forms of partisanship in theory, or to explain their absence in practice. It takes more than zoning permission and a good architect to make a house a home." 234 Imagine trying to run a law school or a political science department, which depends heavily for its success on a widespread willingness to do institutional work and participate in the intellectual life of the institution, with a faculty and staff that responds only to rules, structures, and perceptions of political or financial costs and benefits.

To the extent the objection under consideration is actually focused on the relative realism of institutional structure and role morality and not on their relative efficacy, a final response is that it does not seem fair to criticize role restraints as unrealistic and then turn around and propose structural reforms that may themselves be unrealistic. Because the institutional environment is relatively fixed for the foreseeable future, at least as a general matter, Americans living today are not well situated to think as constitutional framers do. The U.S. Constitution is extraordinarily difficult to amend, whether through the traditional method (initial proposal by two-thirds of each House of Congress), or through the method that has never before been used (a convention of the fifty states called for by two-thirds of the state legislatures). ${ }^{235}$ Either way, it requires only thirteen states to defeat a proposed amendment, and it is very likely that at least thirteen states will reject proposals that are controversial, such as the balanced budget amendment touted by conservative advocacy groups that in recent years have been pursuing a convention of the states. ${ }^{236}$

\footnotetext{
${ }^{231}$ See The Federalist No. 51 (James Madison).

${ }^{232}$ For a discussion of Madison's views, see supra notes 103-113 and accompanying text.

233 See The Federalist No. 51, at 322 (James Madison) (Clinton Rossiter ed., 1961).

${ }^{234}$ Justin Levitt, The Partisanship Spectrum, 55 WM. \& MARY L. REV. 1787, 1829 (2014).

${ }^{235}$ See U.S. CONST. art. V.

${ }^{236}$ See, e.g., Michael Wines, Inside the Conservative Push for States to Amend the Constitution, N.Y.
} TIMES (Aug. 22, 2016), https://www.nytimes.com/2016/08/23/us/inside-the-conservative-push-for-states-to-amendthe-constitution.html. 
That said, some important rules and practices (like the filibuster and regular order ${ }^{237}$ ) are sub-constitutional and do not even require legislation in order to preserve, re-introduce, or terminate. Other problems, including partisan gerrymanders, may be ameliorated through legislation, referenda, or judicial decisions. Again, it is worthwhile to propose and pursue structural changes that would enhance collective self-governance and collective action, including changes that do not seem likely to take place any time soon. But it is hard to see how developing a constitutional role morality alongside structural proposals would make such changes less, as opposed to more, likely to occur.

\section{B. Second Objection: Implementation}

A second, related objection is that the vision offered in this Article faces daunting implementation questions. What incentives do elected officials have to moderate their behavior beyond legality? In an age of hyper-partisanship, do not the bases and donors of the two main political parties pressure elected officials not to moderate, and are not federal judges more insulated from such political pressure? Even worse, to the extent political scientists are correct that the two parties are asymmetrically polarized, ${ }^{238}$ this Article's call for practices of moderation, compromise, mutual respect, and restraint risks being dismissed by one side of the ideological and partisan divide as itself ideological and partisan. ${ }^{239}$

Part IV initiated a conversation about some of those questions: it is important to challenge legal academics to develop a constitutional role morality for elected officials; to

${ }^{237}$ See, e.g., John McCain, It's Time for Congress to Return to Regular Order, WASH. Post (Aug. 31, 2017), https://www.washingtonpost.com/opinions/john-mccain-its-time-congress-returns-to-regularorder/2017/08/31/f62a3e0c-8cfb-11e7-8df5-c2e5cf46c1e2_story.html?utm_term=.77ed4bc6b0b0 (advocating for "a return to regular order, letting committees of jurisdiction do the principal work of crafting legislation and letting the full Senate debate and amend their efforts"); see also Thomas Kaplan \& Robert Pear, McCain Announces Opposition to Republican Health Bill, Likely Dooming It, N.Y. TimES (Sept. 22, 2017), https://www.nytimes.com/2017/09/22/us/politics/mccain-graham-cassidy-health-care.html ("For months, Mr. McCain has lamented a Senate legislative process that avoided hearings or formal bill-drafting procedures and excluded Democrats. On Friday, he said those tactics were intolerable.").

${ }^{238}$ See, e.g., ThOMAS E. MANn \& Norman J. ORnStein, It's Even WORSE than It LoOKS: How the American Constitutional System Collided with the New Politics of Extremism 51-58 (2nd ed. 2016) (surveying evidence indicating that Republican voters and politicians have moved further to the ideological right since the 1970s than Democrats have moved to the left).

${ }^{239}$ For an argument that Republican politicians are, for various reasons, more likely to engage in behavior that disrespects political norms and constitutional conventions, see generally Joseph Fishkin and David E. Pozen, Asymmetric Constitutional Hardball, 118 Colum. L. REV. (forthcoming 2018). See id. at 54 ("[T]he appeal of flouting Washington norms is now very strong among Republican voters, and it takes no great public opinion expertise to see that this appeal was central to the electoral success of President Trump."); id. at 19 (surveying evidence suggesting that Republican partisans are "strikingly more likely than Democratic partisans to reject consensual politics in principle"); see also E. J. Dionne JR., Norman J. ORnStein \& ThOMAS E. MANn, OnE Nation After Trump: A Guide for the Perplexed, the Disillusioned, the Desperate, and the Not-Yet DEPORTED (2017) (arguing, inter alia, that President Trump is less an outlier in American politics and more a reflection of conduct and appeals that have characterized the modern Republican Party). That said, many liberal Democrats are also likely to reject this Article's normative vision as requiring too much sacrifice of substantive agendas to other considerations. 
challenge the public to expect their elected representatives to comply with one; to challenge politicians to live it out; to devote greater, not fewer, resources to civic education; and to stop teaching that politics is a realm in which people get to do pretty much whatever they want within the bounds of the law. But this Article cannot adequately answer questions about implementation. As noted at the outset, solutions to the problem of political polarization and ill will obviously depend upon their causes. ${ }^{240}$ Because this Article has not examined those causes, it has not proposed any short-to-medium-term solutions beyond efforts at education, which may help whatever the primary causes. The Article has instead offered a normative account of the role responsibilities of presidents and members of Congress that, if embraced by politicians and others, would help sustain the constitutional project. The account offered here can be discussed and debated on its own terms - that is, independent of concerns about implementation.

Another implementation problem concerns the strategic environment in which elected officials must act. Even if a politician were persuaded by the account offered here, she could reasonably ask why her "side" of the political aisle should "disarm" without knowing whether the other side would follow suit. There is obviously a collective action problem, and unilateral disarmament is unlikely to prove a good strategy. ${ }^{241}$ A role morality approach works only if it is relatively reciprocal; otherwise, those who adopt it risk being "suckers.",242

That said, several observations are warranted. First, even when acting on a "tit for tat" strategy, there is a potentially important difference between doing so with enthusiasm and doing so with regret. The latter orientation might inspire public expressions of the conviction that a race to the top would be better for all involved than a race to the bottom but that one has no reasonable choice but to respond in kind as a way of punishing the other side's excessive partisanship. $^{243}$

Second, there is a difference between (1) "tit for tat" responses to bad behavior from the other side as a means of sticking up for one's substantive interests and potentially securing better

${ }^{240}$ Contributing factors likely include the transformation of the public sphere through old and new media, demographic changes in the country and their implications for the Republican Party, gerrymandering on technological steroids, and the increased clustering of Democrats in urban areas and Republicans in rural areas. But a responsible examination of the issue is beyond the scope of this Article. For an illuminating study of part of the problem, see generally CASs R. Sunstein, \#REPUbliC: Divided DeMOCRACY In THE AgE Of Social MEDiA (2017) (examining how the Internet is driving political fragmentation, polarization, and extremism).

${ }^{241}$ In the current moment, there is at least an argument that conservatives view liberals as fundamentally illegitimate in a way that most liberals do not view conservatives (setting aside President Trump). For an articulation of that view with respect to legal elites, see Primus, supra note 170 ("Democratic-appointed judges are not to be considered a normal part of the system, fit to exercise adjudicative authority because they too are honorable servants of the Constitution, even if they understand the Constitution differently from the way we understand it. No. They are to be regarded unfit per se.").

${ }^{242}$ See, e.g., Mark Tushnet, Expanding the Judiciary, the Senate Rules, and the Small-c Constitution, BALKINIZATION (Nov. 25, 2017), https://balkin.blogspot.com/2017/11/expanding-judiciary-senate-rules-and.html ("If you think you're playing an iterated game and your opponent thinks otherwise, you are (to use a technical term) a booby. The strategies you use - in particular, refraining from tit-for-tat responses - will be completely ineffective; your opponents will keep on 'tatting,' playing you for a sucker.”).

${ }^{243}$ For discussion of collective action problems, races to the bottom, and races to the top, see Cooter $\&$ Siegel, supra note 134, at 135-44, 161-62. 
behavior in the future, and (2) responses that escalate a conflict, thereby hastening a race to the normative bottom. In other words, one can seek to avoid conflict escalation without unilaterally disarming. ${ }^{244}$ One can no doubt question the usefulness of that distinction, given that what one side views as "tit for tat" the other side may be likely to interpret as conflict escalation. Even so, the distinction is defensible in principle and is applied in practice in a variety of settings. Consider, for example, the distinction in foreign policy circles between economic sanctions and military intervention. Moreover, there may be a difference between how politicians characterize the other side's behavior in public and what they understand to be going on in private.

Finally, is also worth reflecting on whether there are ways of moving beyond "tit for tat" interactions and promoting a race to the top. Doing so would likely require incremental, confidence-building measures and compromises over extended periods of time. For example, if the Democrats had gained control of the Senate in the 2016 elections, they might have done more than simply refuse to confirm any Supreme Court nominee not named Merrick Garland (or someone ideologically similar). They might have also agreed to consider in good faith future Trump nominees once Garland was confirmed.

Notwithstanding concerns about implementation, this Article's proposal is worth taking seriously because it invites legal scholars to recast their thinking on a fundamental level —and arguments on that level find their purchase on one's overall view of the world more than in their short or even medium-term impact on specific decisions. There is a huge difference between a constitutional regime in which there are norms and conventions based on role that are often violated by elected officials, and a regime in which those norms and conventions are simply not thought to exist. This Article is arguing for a reconfiguration of America's world of political decisions. At some point, there is no escaping attention to how the vision could become reality. But in a deeply polarized country in which politicians who hold high office too often act as if there are no non-legal role restraints, the immediate task is to develop the vision itself.

Moreover, it is easy to miss the extent to which norms that constrain the worst forms of partisanship continue to operate in the present. ${ }^{245}$ As bad as the current situation is from the vantage point of the vision articulated in this Article, the truth is that it could be much worse. For example, the Justices are not simply partisans; all (or almost all) of them disappoint the political party that appointed them at least some of the time. There are no serious proposals in the political branches calling for Court-packing or the impeachment of Justices or judges appointed by presidents of the other party. There has not been a wholesale politicization of federal criminal law enforcement, even as the longstanding convention of independence from the president appears to be under pressure. ${ }^{246}$ There is no widespread practice of Republican-appointed

${ }^{244}$ See Neil S. Siegel, Some Notes on Court Packing, Then and Now, BALKINIZATION (Nov. 27, 2017), https://balkin.blogspot.com/2017/11/some-notes-on-court-packing-then-and-now.html (discussing those strategic and normative considerations).

${ }^{245}$ Justin Levitt catalogues numerous examples in the three branches of "many public entities that do not normally behave in tribally partisan fashion, even when substantive rules and institutional structure would make such tribal partisanship possible, and when natural incentives would make it desirable." Levitt, supra note 234, at 1830; see id. at 1831-43 (compiling examples). Levitt concludes that "role morality" and "situational norms" are doing much of the work. Id. at 1843-53.

${ }^{246}$ See, e.g., Peter Baker \& Michael D. Shear, Trump Shifts Rationale for Firing Comey, Calling Him a "Showboat," N.Y. TIMES (May 11, 2017), https:/www.nytimes.com/2017/05/11/us/politics/trump-comey- 
secretaries of state refusing to certify elections that Democrats won based on highly dubious allegations of widespread voter fraud. ${ }^{247}$ There are, of course, examples that potentially count as exceptions to most of the above generalizations, but they do not disprove the rule. ${ }^{248}$ Nor do the generalizations seem entirely explainable in terms of political self-interest. Anyone who thinks that normatively unrestrained partisanship could not get substantially more severe in American politics lacks imagination, knowledge of comparative politics, or awareness of American history. ${ }^{249}$

In addition, it is possible to conceive of circumstances that could make this Article's normative account more realistic in the foreseeable future. For example, given his consistently low poll numbers notwithstanding an increasingly strong economy, ${ }^{250}$ it is at least plausible to imagine that President Trump's reputation as the ultimate norm violator will contribute to his defeat in the 2020 Republican presidential primary or the general election. His prominence in the anticanon of exemplars of constitutional role morality may ultimately prompt more candidates for public office-Republicans and Democrats alike - to develop and deserve reputations for civility and civic virtue. ${ }^{251}$ The causes of polarization would not have changed, but the vision offered here would still seem more realistic than it may now.

At the very least, one can imagine a fruitful agenda for the American Bar Association, the American Constitution Society, the Federalist Society, and patriotic, thoughtful liberals and conservatives in the legal profession. Operating behind a veil of ignorance about who would

showboat-fbi.html (“[F] or the first time, he explicitly referenced the F.B.I.'s investigation into his administration's ties to Russia in defending Mr. Comey's firing."); Betsy Klein, Trump Slams Sessions, Rips DOJ in Twitter Outburst, CNN (July 24, 2017), http://www.cnn.com/2017/07/25/politics/donald-trump-jeff-sessions-hillaryclinton/index.html ("President Donald Trump lashed out at his attorney general and Justice Department in an extraordinary outburst on Twitter Tuesday morning, continuing his public shaming of Jeff Sessions while appearing to prod the nation's top law enforcement official to investigate Hillary Clinton, his 2016 election opponent.").

${ }^{247}$ See, e.g., Allan Smith, Alabama's Republican Secretary of State-Who Voted for Roy Moore-Destroys "Voter Fraud" Claims in CNN Interview, BuS. INSIDER (Dec. 28, 2017), http://www.businessinsider.com/alabamasecretary-of-state-destroys-roy-moore-voter-fraud-2017-12).

${ }^{248}$ See Levitt, supra note 234, at 1853 ("[P] ublic officials with recognizable partisan affiliations can leave behind private tribal partisan impulses when acting in a public capacity, even when their self-interest is implicated. Indeed, our lived experience is that they not only can but repeatedly do, in daily official acts large and small, even when there are opportunities to behave otherwise."); $i d$. ("Some groups of officials have firmer norms against tribal partisanship than others, and these norms are stronger in some circumstances than others. But even the weaker end of the spectrum is stronger than conventional wisdom suggests.").

249 The first political transition-from the hitherto dominant Federalists to the ascendant Democratic Republicans - was so rocky in part because the Founders lacked many of the norms and conventions that manage political transitions today. And so when one side created judgeships at the last minute, the other side terminated them in likely contravention of Article III and canceled a Supreme Court term to postpone judicial resolution of the matter. For discussion of the crisis of 1800-1803, see generally BRUCE ACKERMAN, THE FAILURE OF THE FOUNDING FATHERS: JEFFERSON, MARSHALL, AND THE Rise OF PRESIDENTIAL DEMOCRACY (2007).

250 See, e.g., Chris Cillizza, Donald Trump Is in a Very Bad Polling Place, CNN (Nov. 4, 2017), http://www.cnn.com/2017/11/03/politics/trump-polling/index.html ("Of the 10 major national polls conducted over the past month, the highest - repeat: the highest - Trump's approval rating has been is 38\%. The lowest is 33\%. Trump's average approval rating over those 10 polls is $37.1 \%$. His average disapproval? $57.1 \%$.”).

${ }^{251} C f$., e.g., Greene, supra note 54 (discussing why certain judicial decisions have come to be regarded as "anticanonical"). 
control the federal government at a certain future date, those organizations and individuals could work together to agree upon certain norms of conduct by elected officials in particular settings (for example, judicial nominations and confirmations), and to encourage reciprocity in adhering to those norms. The American Constitution Society is already interested in the topic of norms and conventions, as are some conservatives. ${ }^{252}$ Such a project would face a variety of obstacles in terms of both obtaining sufficient "buy in" and producing agreement on standards that are not so vague as to be meaningless. But doing nothing seems like a clearly inferior alternative. As for the criticism that the project is profoundly antidemocratic-that it is "the Establishment" imposing constraints on democracy - several points developed in this Article bear repeating: most Americans are not nearly as partisan as their representatives and the political class; role restraints are conducive to minority self-governance (and all Americans can expect to be on the losing end of elections in the years ahead); most Americans want the federal government to function reasonably well; and, in any event, successful democracies also require leadership.

\section{CONCLUSION}

Presidents and members of Congress are not federal judges, but nor are they as categorically distinct as most constitutional law scholars have tended to suppose. Such scholars expect judges to be restrained by a constitutional role morality that imposes obligations over and above legal obligations. It is time to expect the same of elected officials.

This Article has been primarily concerned with justifying and inspiring efforts to articulate a constitutional role morality for elected officials of the federal government, not with completing this task on its own. It has grounded constitutional role morality in two purposes of the Constitution that law cannot fully accomplish on its own: the American conception of democracy as collective self-governance, and the perceived desirability, both historically and today, of a reasonably effective federal government. It has suggested for consideration some rhetorical, procedural, and substantive components of such a role morality. The Article has not focused on how to make its normative vision a reality, but it has suggested that, over the longer term, newer forms of civic education and law teaching may make some difference. More immediately and practically, demanding role restraints of elected officials can help license robust practices of political resistance to aggressive ideological agendas that politicians may seek to justify by invoking their victories on Election Day.

Constitutional law scholars, along with scholars of legislation and the legal profession, can further develop the rhetorical, procedural, and substantive components of the role morality sketched here. Alternatively, they can explain why those suggestions ought to be rejected and a different set of role expectations adopted. It is difficult to know what potentially attractive role morality will be developed if legal scholars do not even try. What constitutional law scholars

${ }^{252}$ For example, William Kristol of The Weekly Standard participated enthusiastically on a plenary panel at the June 2017 ACS National Convention on the topic of norms and constitutional conventions. See ACS 2017 National Convention Plenary: Norms, Conventions, and Constitutional Governance, AMERICAN CONSTITUTION SOCIETY (June 9, 2017), https://www.acslaw.org/news/video/acs-2017-national-convention-plenary-normsconventions-and-constitutional-governance. 
should not do is continue writing and teaching as if, as far as the U.S. Constitution is concerned, politicians are free to do whatever they want within the bounds of the law.

Skeptics will no doubt ask - as they should — what incentives elected officials have to moderate their behavior beyond the demands of legality. They may also ask (rhetorically, this time) what, in the absence of such incentives, some "cackling" or, worse, preaching by law professors will ever accomplish. ${ }^{253}$ This Article may perhaps be described as cackling, but it is not a homily. It is, rather, an invitation to look at American political and constitutional arrangements from a different perspective than the usual one. The hope is that some constitutional law scholars and other legal academics will accept the invitation, and that some of them will then expand their beliefs about what is preferable - and even possible - in American politics.

${ }^{253}$ COLlingwoOd, supra note 1 , at 343. 